\title{
Evaluating conservation and fisheries management strategies by linking spatial prioritization software and ecosystem and fisheries modelling tools
}

\author{
Metcalfe Kristian ${ }^{1,{ }^{*}}$, Vaz Sandrine ${ }^{2}$, Engelhard Georg H. ${ }^{3}$, Villanueva Ching-Maria ${ }^{4}$, \\ Smith Robert J. ${ }^{1,}$, Mackinson Steven ${ }^{3, *}$
}

${ }^{1}$ Univ Kent, DICE, Sch Anthropol \& Conservat, Canterbury CT2 7NR, Kent, England.

2 IFREMER, UMR EME 212, F-34200 Sete, France.

${ }^{3}$ Fisheries \& Aquaculture Sci Cefas, Ctr Environm, Lowestoft NR33 OHT, Suffolk, England.

${ }^{4}$ IFREMER, Lab Biol Halieut, Ctr Bretagne, F-29280 Plouzane, France.

* Corresponding authors : Kristian Metcalfe, email address : kristian.metcalfe@exeter.ac.uk ;

Robert J. Smith, email address : r.j.smith@kent.ac.uk ;

Steven Mackinson, email address : steve.mackinson@cefas.co.uk

\begin{abstract}
:
1. Well-designed marine protected area (MPA) networks can deliver a range of ecological, economic and social benefits, and so a great deal of research has focused on developing spatial conservation prioritization tools to help identify important areas.
\end{abstract}

2. However, whilst these software tools are designed to identify MPA networks that both represent biodiversity and minimize impacts on stakeholders, they do not consider complex ecological processes. Thus, it is difficult to determine the impacts that proposed MPAs could have on marine ecosystem health, fisheries and fisheries sustainability.

3. Using the eastern English Channel as a case study, this paper explores an approach to address these issues by identifying a series of MPA networks using the Marxan and Marxan with Zones conservation planning software and linking them with a spatially explicit ecosystem model developed in Ecopath with Ecosim. We then use these to investigate potential trade-offs associated with adopting different MPA management strategies.

4. Limited-take MPAs, which restrict the use of some fishing gears, could have positive benefits for conservation and fisheries in the eastern English Channel, even though they generally receive far less attention in research on MPA network design.

5. Our findings, however, also clearly indicate that no-take MPAs should form an integral component of proposed MPA networks in the eastern English Channel, as they not only result in substantial increases 
in ecosystem biomass, fisheries catches and the biomass of commercially valuable target species, but are fundamental to maintaining the sustainability of the fisheries.

6. Synthesis and applications. Using the existing software tools Marxan with Zones and Ecopath with Ecosim in combination provides a powerful policy-screening approach. This could help inform marine spatial planning by identifying potential conflicts and by designing new regulations that better balance conservation objectives and stakeholder interests. In addition, it highlights that appropriate combinations of no-take and limited-take marine protected areas might be the most effective when making trade-offs between long-term ecological benefits and short-term political acceptability.

Keywords: Ecopath with Ecosim, Ecospace, marine spatial zoning, marine trophic index, Marxan, Marxan with Zones, systematic conservation planning 
Marine ecosystems are increasingly under pressure and, in the rush to safeguard our oceans, conservationists are increasingly pinning their hopes on marine protected areas (MPAs). Thus, nearly 7,318 of these sites, covering $3 \%$ of global ocean area have been established to meet a diverse set of conservation, social and economic objectives, including the management of marine resources (Watson et al. 2014). In particular, there is a growing consensus that by restricting certain activities within their boundaries, MPAs can provide numerous benefits for biodiversity and fisheries (Lester \& Halpern 2008; McCook et al. 2010; Bates et al. 2013). Nonetheless, MPAs remain controversial, and often face strong opposition from resource users who oppose restrictions on where and how they operate (Abbott \& Haynie 2012; Rassweiler, Costello \& Siegel 2012).

In particular, there is often conflict between conservationists and fisheries groups over the types of MPAs proposed as part of a conservation plan (Grantham et al. 2013). For example, despite the socio-economic impacts associated with excluding all activities, no-take MPAs are generally preferred by conservationists because they offer better protection for marine ecosystems, and are easier to manage and enforce (Lester \& Halpern 2008; Ban et al. 2011; Edgar et al. 2014). However, research has shown that partially protected MPAs, which are designed to restrict certain activities, can also provide a range of benefits, such as increased biomass, density, richness and individual size of both target and non-target species, and species of conservation concern (Lester \& Halpern 2008; McCook et al. 2010). Modelling studies have also shown that measures such as reducing fishing effort can be more effective at achieving conservation objectives, either alone, or in combination with MPAs (Zeller \& Reinert 2004). Thus there are inherent trade-offs when choosing between types of MPAs, as no-take MPAs are seen as better for conservation but are often more contentious, making the process of implementation more politically difficult and polarizing (Le Quesne et al. 2008; Lester \& Halpern 2008).

In this context, it is recognised that planners should seek to reduce conflicts when identifying the location and type of MPAs by accounting for social and socio-economic factors, as well as measures of conservation value (Grantham et al. 2013; Klein et al. 2013). Therefore, a commonly used approach to designing MPA networks is systematic conservation planning; a target driven approach that can help identify priority areas that adequately represent species and habitats whilst minimising impacts on fisheries and other sectors (Klein et al. 2013). This generally involves using spatial prioritisation software tools, such as Marxan, which has been developed to identify priority areas efficiently (Ball, Possingham \& Watts 2009). A recent extension of this software, Marxan with Zones, now enables so-called spatial marine zoning by allowing different management and protection zones to be explicitly considered in the analysis, together with their associated socio-economic costs (Watts et al. 2009; Klein et al. 2010).

However, whilst these software tools result in MPA network designs that minimise impacts on stakeholders, they do not consider the impacts of the different types of management proposed by policy makers. This is because they do not explicitly account for ecological processes and dynamics, and so it is difficult to determine the impacts these networks could have on marine ecosystem health and fisheries, or the implications for fisheries sustainability (Grantham et al. 2013). For example, closures and/or gear restrictions may induce shifts in the distribution of fishing effort and the targeting behaviour of fisheries, with potential cascading effects (Abbott \& Haynie 2012). Fortunately, the last decade has seen the development of ecosystem models that can be used to address this problem; so here we demonstrate a novel approach to explore the potential impacts of different MPA management strategies by combining spatial prioritisation software outputs with an ecosystem model. 
To illustrate, we apply this method to the eastern English Channel, a region important for commercial fisheries, but also the focus of several on-going MPA initiatives (Metcalfe et al. 2013). This involved: (1) using Marxan and Marxan with Zones conservation planning software (Ball, Possingham \& Watts 2009; Watts et al. 2009) to identify a range of MPA networks with different management types, based on zoning of fleet access and gear types; and, (2) using a spatially explicit ecosystem model developed in Ecopath with Ecosim (Christensen \& Walters 2004) to investigate their ecological and fisheries impacts. More specifically, given the core problem in accounting for ecosystem dynamics in the planning of spatial management areas we focus on how including different proportions of no-take MPAs relative to limited-take MPAs (i.e. partially protected) impacts ecosystem biomass, fisheries catches, commercially valuable species, and the mean trophic level of landings. In doing so, we demonstrate a policy-screening approach that can help identify potential trade-offs between different management strategies, which is particularly pertinent given global commitments to establish networks of effectively managed MPAs (Watson et al. 2014).

\section{Methods}

\subsection{Marine protected area network design}

We adopted a systematic conservation planning approach because it provides a transparent platform for exploring the role of different management strategies in MPA network design (Grantham, Petersen \& Possingham 2008). The analysis thus followed the principles of MPA network design by representing broad biodiversity surrogates (habitats) and species of conservation concern. This involved: (1) compiling biodiversity data on 34 species and 24 benthic habitat types in the eastern English Channel, known collectively as conservation features (Table S1); (2) setting representation targets (Table S1) for how much of each feature should be protected in UK and French waters; (3) dividing the eastern English Channel into a number of $31.4 \mathrm{~km}^{2}$ planning units (Fig. S1) to match a system developed for an existing Ecospace model (Daskalov, Mackinson \& Mulligan 2011); (4) calculating the amount of each conservation feature in each planning unit; (5) assigning a cost to each planning unit based on vessel monitoring system (VMS) effort data for eight fishing fleets (beam trawls; demersal otter trawls; dredges; pelagic trawls; hooks and lines; nets; seines; and traps and pots); and, (6) using spatial prioritisation software to identify a near-optimal set of planning units (referred to as portfolios hereafter) that when combined meet these representation targets, whilst minimising fragmentation levels and planning unit costs (Ball, Possingham \& Watts 2009; Watts et al. 2009).

We used both the Marxan and Marxan with Zones conservation planning software packages in our analysis. These have the same core functionality, and use the same system for measuring costs based on the summed planning unit costs, a boundary cost that reflects the boundary length of the portfolio edge, and costs for not meeting the conservation feature targets. They both use the simulated annealing approach, which involves running the software a number of times and identifying a series of different portfolios of planning units that meet specified targets whilst minimising costs. Marxan, however, implicitly assumes planning units can be assigned to one of two zones; reserved or not reserved. In contrast, Marxan with Zones is able to assign each planning unit to one of several user-defined management zones, allowing users to set targets for these different management zones and specify how costs vary for a particular planning unit depending on the zone to which it is assigned (Watts et al. 2009).

Given both these software packages identify slightly different near-optimal portfolios each time they are run, we first needed to ensure that our investigation of the ecological impacts of different MPA management scenarios was not masked by underlying spatial differences in the MPA networks. We did this by running Marxan 500 times and using the Cluster Analysis option in Zonae Cogito to identify the five most spatially different portfolios (hereafter 
referred to as priority area maps) that met all the targets and minimised costs (Linke et al. 2011). These five priority area maps then formed the basis of our analysis, where we investigated the impacts of changing the percentage of each priority area map that belonged to two different management zones. These two zones were defined as: (1) 'no-take' that would exclude all fishing fleets; and (2) 'limited-take' that would exclude fleets using mobile bottom gears (beam trawls, demersal otter trawls, dredges), because these gears damage some habitat types and have been linked to stock declines (Roberts, Hawkins \& Gell 2005). To do this we used Marxan with Zones to modify each of the priority area maps and identify six portfolios based on setting targets that $0 \%, 20 \%, 40 \%, 60 \%, 80 \%$ and $100 \%$ of each conservation feature should be assigned to a limited-take MPA, with the rest being assigned to no-take MPAs. For example, the overall target for UK High Energy Infralittoral Rock was $3.6 \mathrm{~km}^{2}$ (Table S1). Thus, in the first scenario $3.6 \mathrm{~km}^{2}(100 \%)$ was assigned to the no-take zone and $0 \mathrm{~km}^{2}(0 \%)$ assigned to the limited-take zone; and in the second scenario $2.88 \mathrm{~km}^{2}$ $(80 \%)$ was assigned to the no-take zone and $0.72 \mathrm{~km}^{2}(20 \%)$ to the limited-take zone, and so forth. We set the cost of establishing no-take MPAs as being the combined cost of all eight fishing fleets (which were used as the planning unit costs in Marxan); whereas the cost for limited-take MPAs was based on fishing costs for the three excluded fleets using mobile bottom gears (see Supporting Information).

\subsection{Ecosystem model}

To describe the temporal and spatial dynamics of the eastern English Channel we used Ecopath with Ecosim, a suite of modelling tools (comprised of Ecopath, Ecosim and Ecospace) that have been widely used to model marine food webs and analyse how changes might affect the structure and functioning of marine ecosystems (Christensen \& Walters 2004). In this study we used Ecospace; a policy evaluation tool based on spatially explicit simulation of ecosystem dynamics to investigate the impact of establishing MPA networks with different proportions of no-take and limited-take zones (Walters, Pauly \& Christensen 1999). The spatial model was based on an existing: (1) Ecopath mass-balance model (Villanueva, Ernande \& Mackinson 2009), that contained data on 51 functional groups (two marine mammal, one seabird, twenty-nine fish, fifteen invertebrate, two primary producers and two non-living groups to represent discard and detritus; Table S2), and nine fisheries (beam trawl; demersal otter trawl; dredges; pelagic trawl; hooks and lines; nets; seine; traps and pots; and other; Table S3); and, (2) Ecosim and Ecospace model (Daskalov, Mackinson \& Mulligan 2011) that was derived from the Ecopath model, and calibrated by comparing model outputs to time series (1973 - 2006) and spatial data from scientific surveys and fish stock assessments (see Supporting Information).

Ecospace simulations are structured around a base-map of cells to describe the two dimensional spatial distribution of biomass for each functional group, and fishing effort over time (Walters, Pauly \& Christensen 1999; Pauly, Christensen \& Walters 2000). Movement between adjacent cells and the distribution of biomass are driven by parameters such as foraging behaviour, avoidance of predation, and dispersal rates that are linked to specific habitat preferences (Walters, Pauly \& Christensen 1999). This region is both physically and ecologically distinct from the adjacent western English Channel and North Sea, but not disconnected, and so application of the ecosystem model can be considered appropriate as the flow of energy within the boundaries is greater than those across (Vaz, Carpentier \& Coppin 2007; Martin et al. 2009). Habitats and functional groups were thus assigned to each cell according to Vaz et al. (2007) who differentiated between four biotic communities in the eastern English Channel (Table S4). Dispersal rates for each functional group (Table S5) were determined from an existing North Sea Ecospace model which were based on published movement rates, and adjusted during Ecosim model calibration (Mackinson \& Daskalov 2007; Daskalov, Mackinson \& Mulligan 2011). For those functional groups with insufficient information, feeding and predation risk parameters that determine the relative dispersal, vulnerability and feeding rates in habitats to which they were not assigned were set to their default values, as per the existing Ecospace model (Table S5). 
In addition, recognising that fishing effort dynamics are important to consider when evaluating MPAs (Stelzenmüller et al. 2008), we specified steaming costs for each fleet based on the location of ports, where costs were calculated for each cell as relative distances to these ports (Daskalov, Mackinson \& Mulligan 2011). We then defined the spatial distribution of the nine fishing fleets by assigning which habitats a fleet may operate in (Table S6) and used the gravity model in Ecospace to predict the spatial distribution of fishing effort, where the proportion of total effort allocated to each cell is assumed proportional to the relative profitability of fishing in that cell (Christensen \& Walters 2004). These distribution maps were then visually inspected to ensure areas predicted as high effort in Ecospace reflected those of high cost in Marxan. This is important, because if there are large discrepancies one can assume that there are underlying issues with either the cost data used in Marxan or the distribution of fishing effort predicted by Ecospace that needs to be resolved to have confidence in the outputs derived from this process.

\subsection{Simulating the potential impact of different management strategies}

To simulate the potential ecosystem responses to the different forms of management we first ran Ecospace for 50 years until the distribution of biomass in the cells was equilibrated (i.e. the model was balanced prior to introducing management changes). We then overlaid each MPA portfolio onto the base-map and assigned which fleet could operate in each MPA according to their gear restrictions (Table S6), and ran Ecospace over a 50 year period (at 0.083 time intervals which are equal to monthly time steps). To examine how each management scenario affected ecosystem functioning and fisheries, we: (1) compared the density of total and exploited ecosystem biomass and fisheries catches to baseline simulations of the eastern English Channel with no MPAs (i.e. fishing effort maintained at status quo); (2) examined changes in the density of total and exploited ecosystem biomass inside and outside of MPAs at the end of the 50 year simulations relative to when MPAs were introduced (year 0); and, (3) investigated changes in the density of biomass inside and outside of MPAs for 13 functional groups (Adult Cod, Dab, Gurnards, Hake, Mackerel, Adult Plaice, Pollack, Adult Seabass, Seabream, Scad, Sole, Rays and Dogfish, and Adult Whiting; Table S2) of importance to commercial fisheries in the eastern English Channel (Martin et al. 2009). To reflect the exploited part of the system we included only higher trophic level and commercially valuable functional groups, with a trophic level $\geq 2.35$ ( $n=$ 29 ). This cut-off value was determined post-hoc as $43 \%$ of the ecosystem biomass occurs below this trophic level due to the high abundance of benthic invertebrates and molluscs in the eastern English Channel (Table S2).

Finally, to evaluate the implications for fisheries sustainability we used the 'Marine Trophic Index' (MTI). Whilst this indicator is often contested (Essington, Beaudreau \& Wiedenmann 2006 ) it is currently endorsed by the Convention on Biological Diversity and is increasingly used to report changes in the health and stability of a marine ecosystem or area (CBD 2004). The MTI is a measure of the mean trophic level of fisheries catches, thus a decrease in the MTI represents a decline in the abundance and diversity of higher trophic level species, highlighting that stocks are being overexploited and fisheries are not being managed sustainably as the trophic level of exploited species decreases (Pauly \& Watson 2005). We calculated the MTI for the total fisheries catch for each year $y$ as follows:

$$
T L_{y}=\frac{\sum_{i}\left(T L_{i} * Y_{i y}\right)}{\sum_{i} Y_{i y}}
$$

Where $T L i$ is the trophic level for functional group $i$ as estimated by Ecopath (Table S2), and Yiy is the catch of the functional group $i$ in year $y$ as provided by Ecospace. In addition, based on recommendations that this should be calculated to emphasise changes in higher trophic level and commercially valuable species that are often at a greater risk of overexploitation (Pauly \& Watson 2005; Araujo et al. 2008), we also calculated the MTI to reflect changes in the exploited part of the system (trophic level $\geq 2.35 ; n=29$ ). 


\subsection{Ecosystem biomass}

The Ecospace model revealed that each of the proposed MPA management scenarios (Fig. 1) resulted in an increase in the density of total and exploited ecosystem biomass compared to a system with no MPAs (baseline scenario), particularly for MPA networks comprised of a large proportion of no-take zones (Fig. 2a; Fig. 2b). However, the change in total ecosystem biomass was typically smaller (Fig. 2a) than the change in exploited ecosystem biomass across each MPA management scenario (Fig. 2b). For example, after 50 years a MPA network comprised of $100 \%$ limited-take zones increased the mean density of total and exploited ecosystem biomass by $0.19 \%$ and $3.41 \%$ relative to the baseline scenario. In contrast, a $100 \%$ no-take MPA network increased the mean density of total and exploited ecosystem biomass by $0.85 \%$ and $14.01 \%$.

Additionally, each of the proposed MPA management scenarios resulted in an increase in the density of total and exploited ecosystem biomass inside no-take and limited-take zones (Fig. 2c; Fig. 2d). The change in ecosystem biomass, however, was greater for MPA networks that were comprised of a large proportion of no-take zones (Fig. 2c; Fig. 2d). For example, after 50 years a MPA network comprised of $100 \%$ limited-take zones increased the mean density of total and exploited ecosystem biomass inside of limited-take zones by $0.56 \%$ and $8.60 \%$. In contrast, the implementation of a $100 \%$ no-take MPA network increased the mean density of total and exploited ecosystem biomass inside of no-take zones by $2.27 \%$ and $39.30 \%$. However, even though the change in density of total ecosystem biomass remained relatively constant outside of MPAs, increasing by approximately $0.5 \%$ across all MPA management scenarios (Fig. $2 \mathrm{c}$ ), the density of exploited ecosystem biomass (trophic level $\geq 2.35$ ) outside of MPAs decreased by approximately $5 \%$ (Fig. 2d).

\subsection{Fisheries catches}

The Ecospace model showed that each of the proposed MPA management scenarios also had a similarly positive impact on fisheries catches in the eastern English Channel, resulting in an increase in the density of total and exploited catches (Fig. 3a; Fig. 3b). For example, after 50 years a MPA network comprised of $100 \%$ limited-take zones increased the mean total and exploited catch by $0.27 \%$ and $2.07 \%$ relative to the baseline scenario. In contrast, a $100 \%$ no-take MPA network increased the mean total and exploited catch by $34.5 \%$ and $39.5 \%$ respectively. There was, however, an initial decrease in fisheries catches following MPA establishment (Fig. 3a; Fig. 3b). Whilst this decrease was greater for MPA networks that had a large proportion of no-take zones, catches typically took longer to return to baseline levels for MPA networks comprised of a large proportion of limited-take zones (Fig. 3a; Fig. 3b). For example, total and exploited catches took 37.4 and 18.9 years respectively to return to baseline levels for a MPA network comprised of $100 \%$ limited-take zones, whereas total and exploited catches took 3.7 and 3.4 years to return to baseline levels for a $100 \%$ no-take MPA network. However, not all fisheries fleets benefitted from MPA establishment, this was particularly evident for fleets using mobile bottom gears (i.e. trawls and dredges), which generally experienced a small decline in fisheries catches across all MPA management scenarios as a result of being excluded from operating in both no-take and limited-take zones (Fig. S2).

\subsection{Commercially valuable species}

In the context of multispecies environments, the Ecospace model showed there are winners and losers associated with the different MPA management strategies, with some functional groups benefiting more from protection than others (Table S7). In terms of target species, the density of biomass for the 13 functional groups of particular value to commercial fisheries increased inside both no-take and limited-take zones across all the proposed management 
scenarios (Table 1). However, this increase was generally greater for MPA networks dominated by no-take MPAs, highlighting that the exclusion of all gears from MPAs is likely to result in substantially larger increases in the biomass of target species than the exclusion of mobile bottom gears only (i.e. trawls and dredges). For example, for MPA networks comprised of $100 \%$ limited-take zones there was on average a $104 \%, 50 \%$ and $1046 \%$ increase in biomass inside MPA boundaries for sole, seabass and plaice, whereas a $100 \%$ no-take MPA increased the biomass of these species by $171 \%, 227 \%$ and $2483 \%$ respectively.

\subsection{Mean trophic level of catches}

Under baseline simulations with no MPAs the mean trophic level of total catches after 50 years was 3.22 (Fig. 3c), and the mean trophic level of exploited catches was 3.48 (Fig. 3d). The Ecospace model highlighted that each of the proposed MPA management scenarios had a positive impact on both the mean trophic level of total catches, which increased across all MPA management scenarios (Fig. 3c), and the mean trophic level of exploited catches (higher trophic level and commercially valuable functional groups), which were generally quite resistant to changes in management (Fig. 3d). There was, however, a very small decrease $(<0.3 \%)$ in the mean trophic level of exploited catches relative to the baseline (i.e. fishing effort maintained at status quo) for MPA networks dominated by limited-take zones (Fig. 3d). For example, after 50 years the mean trophic level of exploited catches for a $100 \%$ limited-take zone MPA network was 3.47; whereas the mean trophic level of exploited catches for a $100 \%$ no-take MPA network was 3.51 .

\section{Discussion}

\subsection{Spatial marine zoning}

Designing MPA networks that balance conservation and industry objectives has moved to the forefront of conservation planning. A key aspect of this involves working with relevant stakeholders and implementing agencies to develop a better understanding of the opportunities and costs associated with each type of conservation intervention (Klein et al. 2010). This is why spatial marine zoning has captured the interest of conservation practitioners as a means to protect biodiversity and manage fisheries, as it can spatially separate incompatible human activities and reduce conflict among user groups (Crowder et al. 2006). Spatial marine zoning can also result in a reduced short-term socio-economic impact on fisheries, a more equitable impact on different fishing sectors, and a considerable increase in profits (Klein et al. 2010; Rassweiler, Costello \& Siegel 2012). However, even with spatial marine zoning there are almost inevitably trade-offs between conservation and fisheries objectives, regardless of whether systematic conservation planning has been used to help minimise these socio-economic impacts (Klein et al. 2008). Thus, if these trade-offs are not made transparent during the planning process then we may not adequately conserve marine biodiversity or foster sufficient stakeholder support for conservation interventions (Klein et al. 2010).

Faced with these issues it is important that policy makers assess the value of different management strategies, especially if they want to understand whether the benefits of notake MPAs justify the costs of their implementation, or whether others forms of spatial management could achieve similar results (Rassweiler, Costello \& Siegel 2012). More importantly, stakeholders increasingly want to know how rapidly changes will occur after protection, even if natural variability can be difficult to predict (Babcock et al. 2010). Therefore, our approach that links these widely used software tools could be used for policy screening to address these types of questions, and so inform future management decisions by identifying potential trade-offs prior to implementation. 
For example, in this study we show that broader classes of MPA management based on zoning of fleet access and gear types not only reduce impacts on stakeholders in the eastern English Channel (Fig. S3) echoing the findings of similar studies (Klein et al. 2010), but could also provide conservation and fisheries benefits, which is important given that no-take MPAs are increasingly unpopular with the fishing sector in this region (Jones 2009). In particular, zoning of fleet access and gear types could represent a more politically feasible management strategy when compared to no-take MPAs that effectively exclude all access. Thus, in cases where zoning could result in long-term increases in target species biomass and fisheries yields as well as maintaining the sustainability of the fisheries, this information could help develop new regulations with broader stakeholder support (Rassweiler, Costello \& Siegel 2012). In addition, excluding mobile bottom gears (i.e. trawls and dredges) from MPAs is likely to have positive conservation outcomes, leading to the restoration of habitat complexity and structure (Roberts, Hawkins \& Gell 2005). This study, however, also clearly indicates that no-take zones should form an integral component of proposed MPA networks in the eastern English Channel, as they not only result in substantial increases in total and exploited ecosystem biomass, fisheries catches and the biomass of commercially valuable species, but are fundamental to maintaining the sustainability of the fisheries. Moreover, beyond their value to fisheries, no-take MPAs also contribute to biodiversity conservation goals, as they are often characterised by improved ecosystem health and resilience, and so can act as an insurance policy against management failures elsewhere (Roberts, Hawkins \& Gell 2005; McCook et al. 2010).

Despite the overall positive impact of introducing spatial management restrictions there was an initial decrease in fisheries catches following MPA establishment, with the greatest impact associated with MPA networks comprised of a large proportion of no-take zones. However, it is worth highlighting that increases in catches often took decades longer to return to baselines levels when reducing the number of no-take MPAs in a network to one dominated by limited-take MPAs. This is likely because MPA networks comprised of a large proportion of no-take zones effectively reduce the available area open to fisheries, in contrast to MPA networks dominated by limited-take zones, which are less restrictive. Consequently, larger quantities of biomass are likely to build up inside MPA networks dominated by no-take MPAs and so spill over and/or migrate into surrounding areas, thereby contributing to increased fisheries catches more quickly than compared to MPA networks dominated by limited-take MPAs. These findings thus highlight an inherent trade-off associated with adopting less contentious management strategies that is likely to have important and long-term economic consequences for fishers.

\subsection{Linking spatial prioritisation software and ecosystem models}

This study is the first to link these two widely used tools and so it is important to acknowledge their assumptions and potential limitations if they are to be used to inform policy. First, ecosystem models will only be as good as the data that are used to create them. In particular, there is often some uncertainty surrounding the baseline model inputs that are used in Ecopath with Ecosim (Araujo et al. 2008), especially when accounting for the complexity of the interactions between the various components (i.e. species and habitats) in an ecosystem (Plaganyi \& Butterworth 2004). Second, ecosystem simulations show expected outcomes for an environment that is structured in the same way as when the simulations begin, and so they do not address temporal changes in species distributions and interactions that could occur over time as a result of climate change, as has already been demonstrated in this region (Genner et al. 2004). Third, ecosystem models assume that the system is closed and that all the energy is consumed from within the system. Thus, if species are known to move outside of the modelled system (i.e. pelagic species) the model may not make accurate predictions. Consequently, the results of these models should be considered in qualitative rather than quantitative terms as an aid to discussions on determining the appropriate type of management intervention (Araujo et al. 2008). Although, where there is uncertainty this approach could be used to investigate particular scenarios in more detail, accounting for complexities in trophic dynamics, changes in species distributions and interactions, and variability in fishing effort to ensure that predictions are 
based on a range of scenarios. This is important as model comparisons can result in a greater understanding of the likely effects of perturbations and management changes in an ecosystem (Fulton \& Smith 2004).

Nevertheless, in the absence of few alternatives linking these widely used tools has the potential to make an important contribution to global conservation and fisheries management efforts (ICES 2012) as they may predict, or at least provide warnings against otherwise unknown, undesirable or counterintuitive responses to changes in management that are often proposed as part of conservation plans (Araujo et al. 2008; Dichmont et al. 2013). Moreover, MPAs are not just fishery management tools and so given that the success of MPAs in meeting conservation objectives depends on user compliance, a key benefit of this approach is that it can be used to screen differing policy objectives (e.g. reference areas, offsets, oil and gas protected areas) and MPA zoning regulations (e.g. no-take, limited-take, cultural sites, and community fishing areas) proposed by a range of stakeholders. This would require: (1) identifying the different types of management options that fit within existing policy frameworks; (2) using spatial prioritisation software to identify a range of MPA networks that meet these objectives; and (3) using ecosystem models to inform stakeholders of the potential ecological responses to different types of management options; rather than making the commonplace assumption that the resultant MPA networks identified by these software tools would benefit biodiversity and fisheries.

Additionally, given that planning unit costs are known to influence the location of priority areas (Ban \& Klein 2009), these tools should be combined to investigate how different cost data used in Marxan could impact fisheries outcomes. Whilst this is likely to be complicated by the diverse group of stakeholders who operate in this sector, this is important as global conservation targets based on area alone will not optimise protection of marine biodiversity (Edgar et al. 2014). More specifically, for MPA networks to be effective management tools, regulations need to be strategically designed to foster stakeholder support and ensure user compliance (McCook et al. 2010; Rassweiler, Costello \& Siegel 2012; Edgar et al. 2014) and so future work linking these tools should consider a range of actors and costs in the planning process.

\section{Acknowledgements}

This study was funded by the European Union Interreg IVA Programme as part of the Channel Integrated Approach for Marine Resource Management Project. S. M. acknowledges support from Defra projects M1202, M1228 for Cefas contributions to the development of the Ecospace model. We are grateful to Ifremer, Cefas, JNCC, European Register of Marine Species and Crown Estate for providing data; and to C.M. Roberts, D.L. Roberts, B. Stoker and two anonymous referees for constructive comments.

\section{References}

Abbott, J.K. \& Haynie, A.C. (2012) What are we protecting? Fisher behavior and the unintended consequences of spatial closures as a fishery management tool. Ecological Applications, 22, 762-777.

Araujo, J.N., Mackinson, S., Stanford, R.J. \& Hart, P.J.B. (2008) Exploring fisheries strategies for the western English Channel using an ecosystem model. Ecological Modelling, 210, 465-477.

Babcock, R.C., Shears, N.T., Alcala, A.C., Barrett, N.S., Edgar, G.J., Lafferty, K.D., McClanahan, T.R. \& Russ, G.R. (2010) Decadal trends in marine reserves reveal differential rates of change in direct and indirect effects. Proceedings of the National Academy of Sciences of the United States of America, 107, 18256-18261. 
Ball, I.R., Possingham, H.P. \& Watts, M.E. (2009) Marxan and relatives: Software for spatial conservation prioritisation. Spatial conservation prioritisation: Quantitative methods and computational tools (eds A. Moilanen, K.A. Wilson \& H.P. Possingham). Oxford University Press, Oxford, UK.

Ban, N.C., Adams, V., Pressey, R.L. \& Hicks, J. (2011) Promise and problems for estimating management costs of marine protected areas. Conservation Letters, 4, 241-252.

Ban, N.C. \& Klein, C.J. (2009) Spatial socioeconomic data as a cost in systematic marine conservation planning. Conservation Letters, 2, 206-215.

Bates, A.E., Barrett, N.S., Stuart-Smith, R.D., Holbrook, N.J., Thompson, P.A. \& Edgar, G.J. (2013) Resilience and signatures of tropicalization in protected reef fish communities. Nature Climate Change, 4, 62-67.

CBD (2004) COP 7 (DecisionVII/30 Strategic Plan: future evaluation of progress) Convention on Biological Diversity. Kuala Lumpur, Malaysia.

Christensen, V. \& Walters, C.J. (2004) Ecopath with Ecosim: methods, capabilities and limitations. Ecological Modelling, 172, 109-139.

Crowder, L.B., Osherenko, G., Young, O.R., Airamé, S., Norse, E.A., Baron, N., Day, J.C., Douvere, F., Ehler, C.N. \& Halpern, B.S. (2006) Resolving mismatches in US ocean governance. Science, 313, 617-618.

Daskalov, G.M., Mackinson, S. \& Mulligan, B. (2011) Modelling possible food-web effects of aggregate dredging in the eastern English Channel. Marine Environmental Protection Fund (MEPF). Ref No: MEPF 08/P37.

Dichmont, C.M., Ellis, N., Bustamante, R.H., Deng, R., Tickell, S., Pascual, R., LozanoMontes, H. \& Griffiths, S. (2013) Evaluating marine spatial closures with conflicting fisheries and conservation objectives. Journal of Applied Ecology, 50, 1060-1070.

Edgar, G.J., Stuart-Smith, R.D., Willis, T.J., Kininmonth, S., Baker, S.C., Banks, S., Barrett, N.S., Becerro, M.A., Bernard, A.T. \& Berkhout, J. (2014) Global conservation outcomes depend on marine protected areas with five key features. Nature, 506 216-220.

Essington, T.E., Beaudreau, A.H. \& Wiedenmann, J. (2006) Fishing through marine food webs. Proceedings of the National Academy of Sciences, 103, 3171-3175.

Fulton, E.A. \& Smith, A.D.M. (2004) Lessons learnt from a comparison of three ecosystem models for Port Phillip Bay, Australia. African Journal of Marine Science, 26, 219243.

Genner, M.J., Sims, D.W., Wearmouth, V.J., Southall, E.J., Southward, A.J., Henderson, P.A. \& Hawkins, S.J. (2004) Regional climatic warming drives long-term community changes of British marine fish. Proceedings of the Royal Society of London. Series B: Biological Sciences, 271, 655-661.

Grantham, H.S., Agostini, V.N., Wilson, J., Mangubhai, S., Hidayat, N., Muljadi, A., Muhajir, Rotinsulu, C., Mongdong, M., Beck, M.W. \& Possingham, H.P. (2013) A comparison of zoning analyses to inform the planning of a marine protected area network in Raja Ampat, Indonesia. Marine Policy, 38, 184-194.

Grantham, H.S., Petersen, S.L. \& Possingham, H.P. (2008) Reducing bycatch in the South African pelagic longline fishery: the utility of different approaches to fisheries closures. Endangered Species Research, 5, 291-299. 
ICES (2012) Report of the Working Group on Multispecies Assessment Methods (WGSAM), 22-26 October 2012, Venice, Italy. ICES CM 2012/SSGSUE:10. 145 pp.

Jones, P. (2009) Equity, justice and power issues raised by no-take marine protected area proposals. Marine Policy, 33, 759-765.

Klein, C.J., Steinback, C., Scholz, A.J. \& Possingham, H.P. (2008) Effectiveness of marine reserve networks in representing biodiversity and minimizing impact to fishermen: a comparison of two approaches used in California. Conservation Letters, 1, 44-51.

Klein, C.J., Steinback, C., Watts, M., Scholz, A.J. \& Possingham, H.P. (2010) Spatial marine zoning for fisheries and conservation. Frontiers in Ecology and the Environment, 8, 349-353.

Klein, C.J., Tulloch, V.J., Halpern, B.S., Selkoe, K.A., Watts, M.E., Steinback, C., Scholz, A. \& Possingham, H.P. (2013) Tradeoffs in marine reserve design: habitat condition, representation, and socioeconomic costs. Conservation Letters, 6, 324-332.

Le Quesne, W.J.F., Arreguín-Sánchez, F., Albañez-Lucero, M., Cheng, H., Cruz Escalona, V.H., Daskalov, G., Ding, H., González Rodríguez, E., Heymans, J.J., Jiang, H., Lercari, D., López-Ferreira, C., López-Rocha, J.A., Mackinson, S., Pinnegar, J.K., Polunin, N.V.C., Wu, J., Xu, H. \& Zetina-Rejón, M.J. (2008) Analysing ecosystem effects of selected marine protected areas with Ecospace spatial ecosystem models. Fisheries Centre Research Reports 16 (2). Fisheries Centre, University of British Columbia, Vancouver.

Lester, S.E. \& Halpern, B.S. (2008) Biological responses in marine no-take reserves versus partially protected areas. Marine Ecology Progress Series, 367, 49-56.

Linke, S., Watts, M., Stewart, R. \& Possingham, H.P. (2011) Using multivariate analysis to deliver conservation planning products that align with practitioner needs. Ecography, 34, 203-207.

Mackinson, S. \& Daskalov, G. (2007) An ecosystem model of the North Sea to support an ecosystem approach to fisheries management: description and parameterisation. Science Series Technical Report no.142, Cefas, Lowestoft.

Martin, C.S., Carpentier, A., Vaz, S., Coppin, F., Curet, L., Dauvin, J.C., Delavenne, J., Dewarumez, J.M., Dupuis, L., Engelhard, G., Ernande, B., Foveau, A., Garcia, C., Gardel, L., Harrop, S., Just, R., Koubbi, P., Lauria, V., Meaden, G.J., Morin, J., Ota, Y., Rostiaux, E., Smith, R.J., Spilmont, N., Verin, Y., Villanueva, C. \& Warembourg, C. (2009) The Channel habitat atlas for marine resource management (CHARM): an aid for planning and decision-making in an area under strong anthropogenic pressure. Aquatic Living Resources, 22, 499-508.

McCook, L.J., Ayling, T., Cappo, M., Choat, J.H., Evans, R.D., De Freitas, D.M., Heupel, M., Hughes, T.P., Jones, G.P., Mapstone, B., Marsh, H., Mills, M., Molloy, F.J., Pitcher, C.R., Pressey, R.L., Russ, G.R., Sutton, S., Sweatman, H., Tobin, R., Wachenfeld, D.R. \& Williamson, D.H. (2010) Adaptive management of the Great Barrier Reef: A globally significant demonstration of the benefits of networks of marine reserves. Proceedings of the National Academy of Sciences, 107, 18278-18285.

Metcalfe, K., Roberts, T., Smith, R.J. \& Harrop, S.R. (2013) Marine conservation science and governance in North-West Europe: Conservation planning and international law and policy. Marine Policy, 39, 289-295.

Pauly, D., Christensen, V. \& Walters, C. (2000) Ecopath, Ecosim, and Ecospace as tools for evaluating ecosystem impact of fisheries. Ices Journal of Marine Science, 57, 697706. 
Pauly, D. \& Watson, R. (2005) Background and interpretation of the 'Marine Trophic Index' as a measure of biodiversity. Philosophical Transactions of the Royal Society BBiological Sciences, 360, 415-423.

Plaganyi, E.E. \& Butterworth, D.S. (2004) A critical look at the potential of Ecopath with Ecosim to assist in practical fisheries management. African Journal of Marine Science, 26, 261-287.

Rassweiler, A., Costello, C. \& Siegel, D.A. (2012) Marine protected areas and the value of spatially optimized fishery management. Proceedings of the National Academy of Sciences, 109, 11884-11889.

Roberts, C.M., Hawkins, J.P. \& Gell, F.R. (2005) The role of marine reserves in achieving sustainable fisheries. Philosophical Transactions of the Royal Society B-Biological Sciences, 360, 123-132.

Stelzenmüller, V., Maynou, F., Bernard, G., Cadiou, G., Camilleri, M., Crec'hriou, R., Criquet, G., Dimech, M., Esparza, O., Higgins, R., Lenfant, P. \& Pérez-Ruzafa, Á. (2008) Spatial assessment of fishing effort around European marine reserves: Implications for successful fisheries management. Marine Pollution Bulletin, 56, 2018-2026.

Vaz, S., Carpentier, A. \& Coppin, F. (2007) Eastern English Channel fish assemblages: measuring the structuring effects of habitats on distinct sub-communities. Ices Journal of Marine Science, 64, 271-287.

Villanueva, M.C., Ernande, B. \& Mackinson, S. (2009) Trophic Network. In Channel habitat atlas for marine resource management, final report (CHARM phase II). Interreg 3a Programme. Carpentier, A., Martin, C.S. and Vaz, S. (eds): IFREMER, Boulogne-surmer, France.

Walters, C., Pauly, D. \& Christensen, V. (1999) Ecospace: Prediction of mesoscale spatial patterns in trophic relationships of exploited ecosystems, with emphasis on the impacts of marine protected areas. Ecosystems, 2, 539-554.

Watson, J.E.M., Dudley, N., Segan, D.B. \& Hockings, M. (2014) The performance and potential of protected areas. Nature, 515, 67-73.

Watts, M.E., Ball, I.R., Stewart, R.S., Klein, C.J., Wilson, K., Steinback, C., Lourival, R., Kircher, L. \& Possingham, H.P. (2009) Marxan with Zones: Software for optimal conservation based land- and sea-use zoning. Environmental Modelling \& Software, 24, 1513-1521.

Zeller, D. \& Reinert, J. (2004) Modelling spatial closures and fishing effort restrictions in the Faroe Islands marine ecosystem. Ecological Modelling, 172, 403-420. 
Figures 
Figure 1 Spatial configuration of the six MPA network portfolios produced in Marxan with Zones for each of five priority area maps identified by Marxan, where an increasing proportion of the targeted amount of each conservation feature is allocated to the limitedtake zone (100 NT, 80 NT, 60 NT, 40 NT, 20 NT, 100 LT).

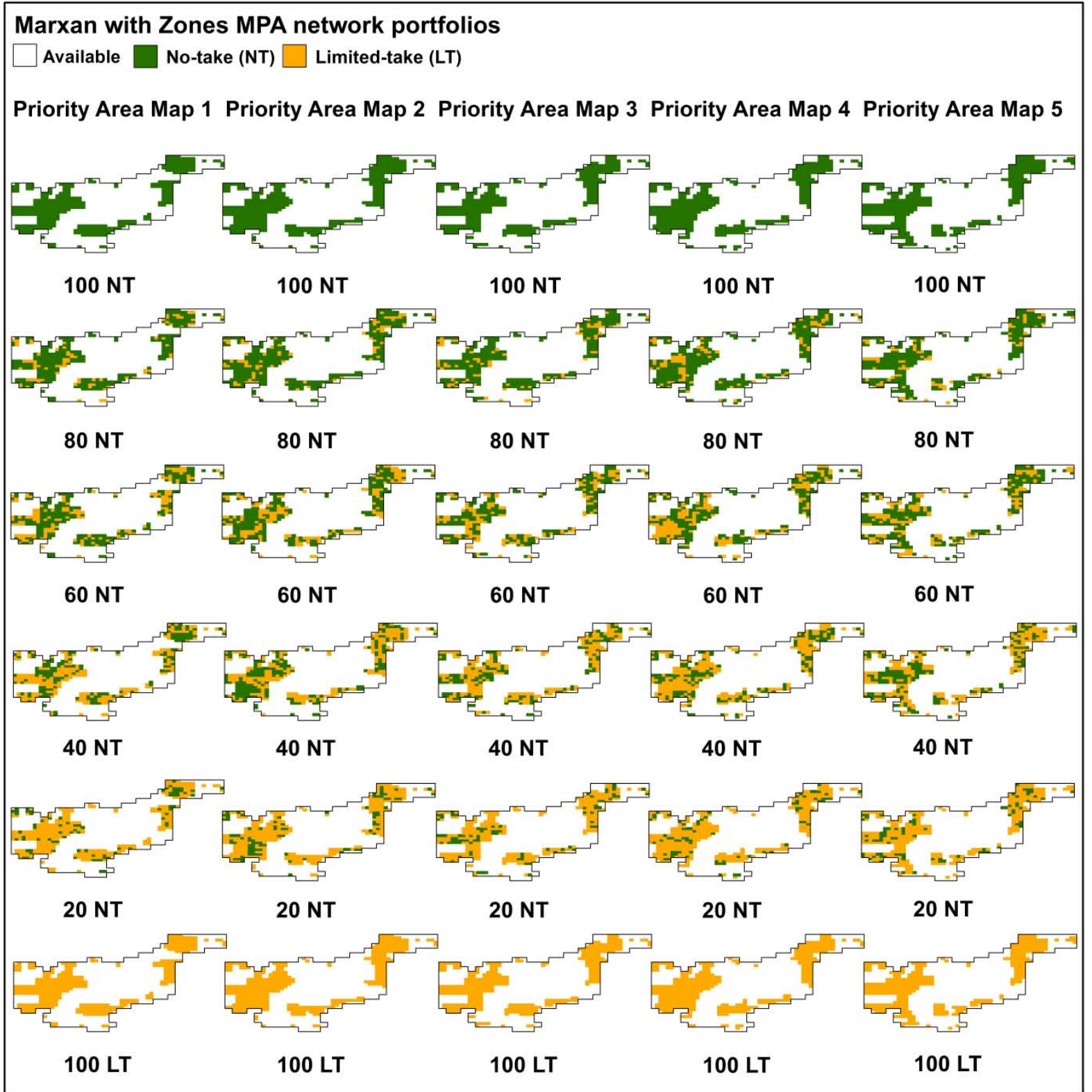


Figure 2 Change over time (0-50 years) in mean (a) total and (b) exploited ecosystem biomass $\left(\mathrm{t} / \mathrm{km}^{2}\right.$ ) relative to the baseline scenario with no MPAs (as indicated by solid red line); and, mean percentage change ( $\pm 95 \%$ confidence intervals) in the density of (c) total and (d) exploited ecosystem biomass inside and outside of MPAs for each management scenario at the end of the 50 year simulations relative to when the MPA was introduced (year 0).

(a)

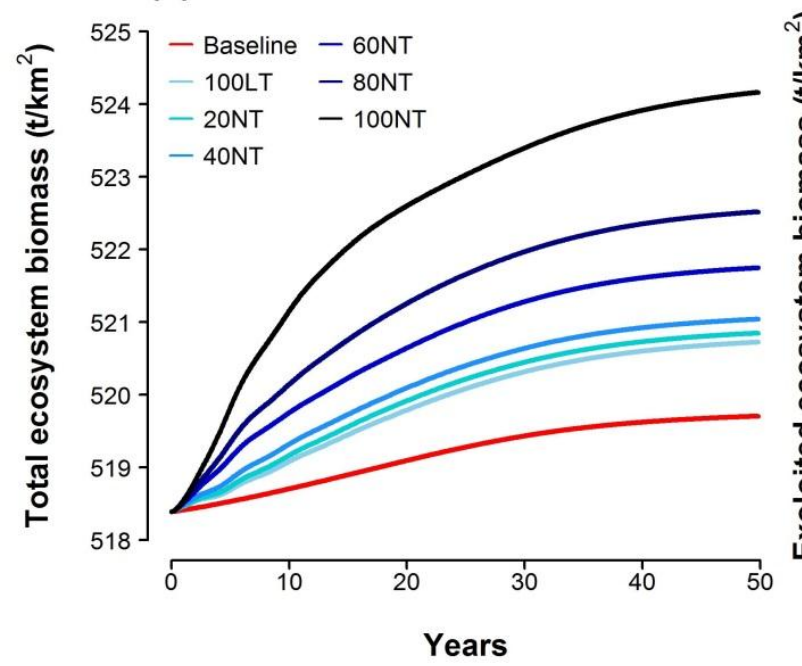

(c)

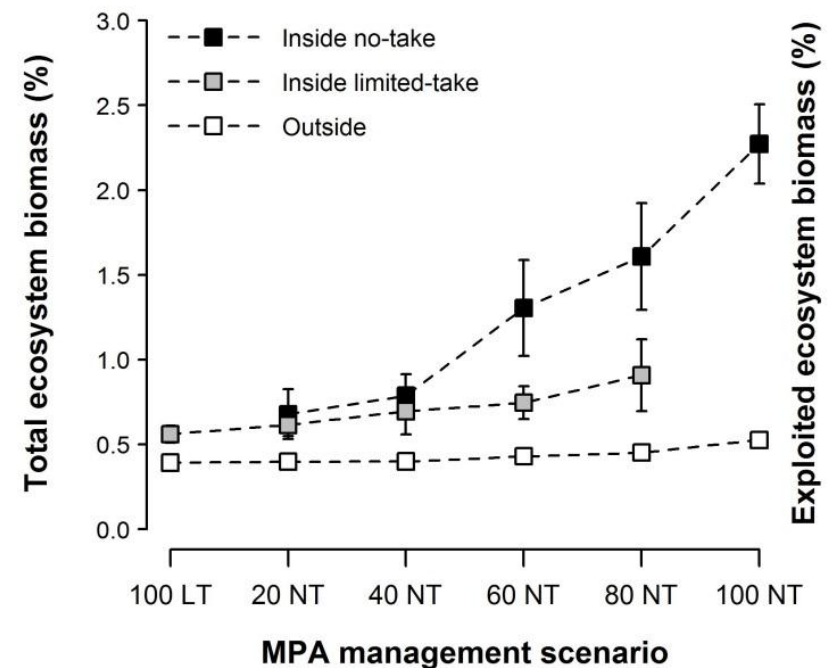

(b)

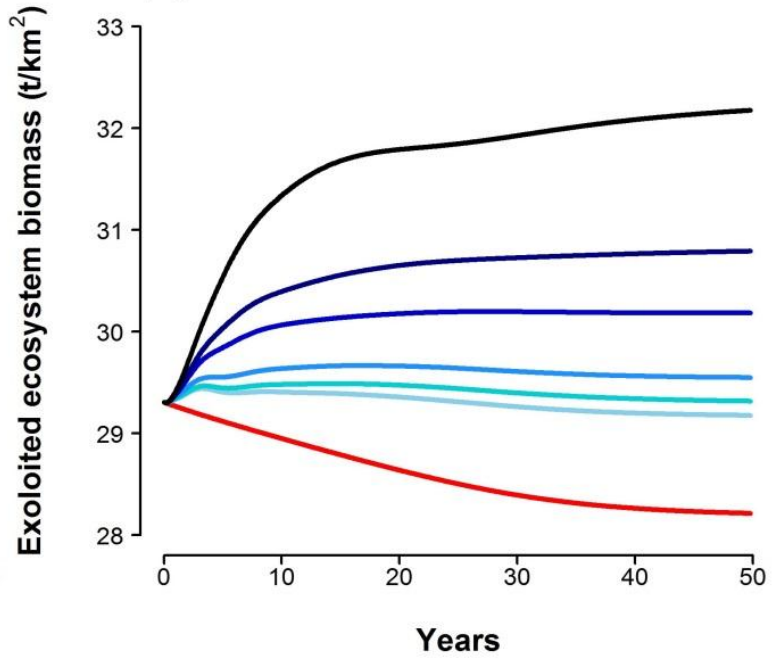

(d)

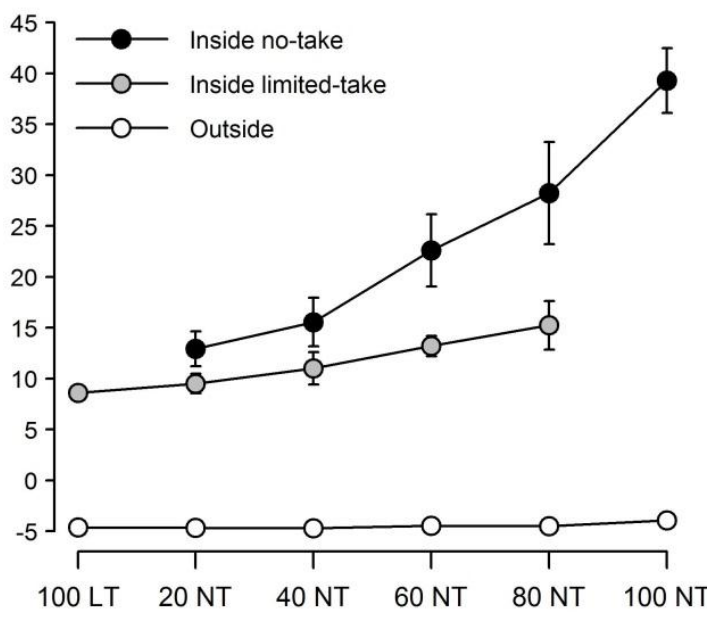

MPA management scenario 
Figure 3 Change over time ( $0-50$ years) in mean (a) total and (b) exploited fisheries catches $\left(\mathrm{t} / \mathrm{km}^{2}\right)$; and mean trophic level of (c) total and (d) exploited catches for each MPA management scenario relative to the baseline scenario with no MPAs (as indicated by solid red line).

(a)

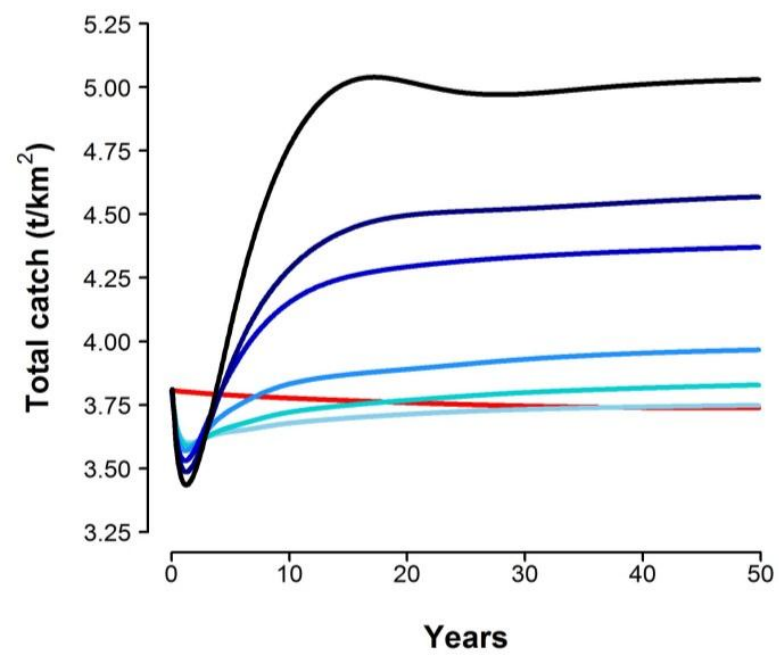

(c)

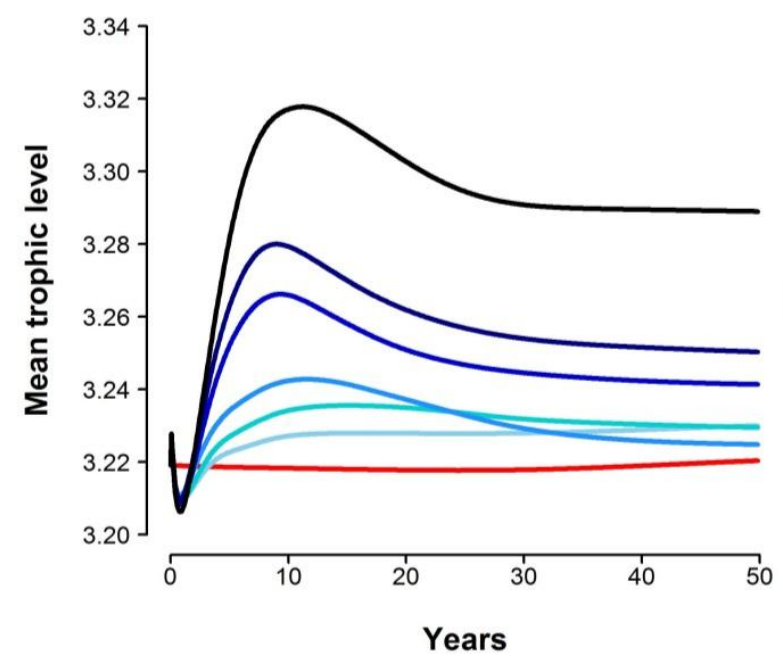

(b)

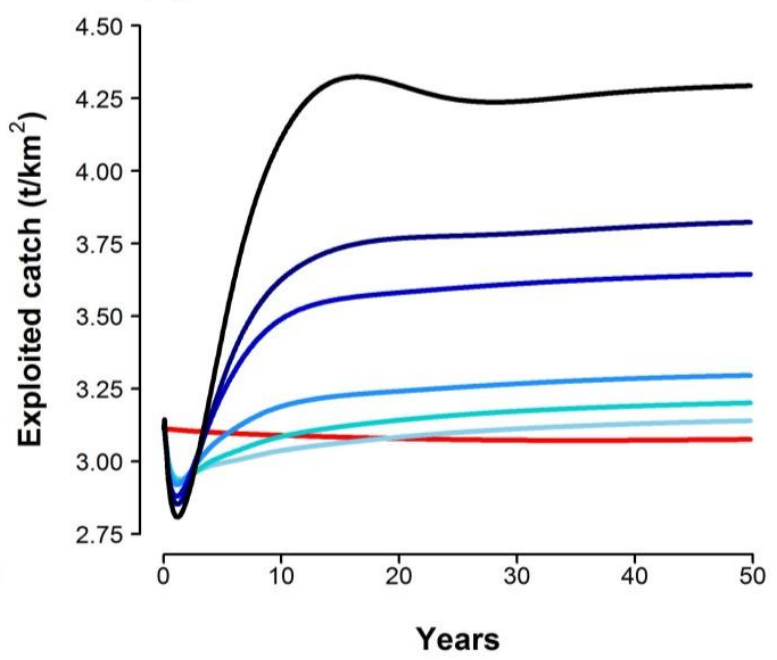

(d)

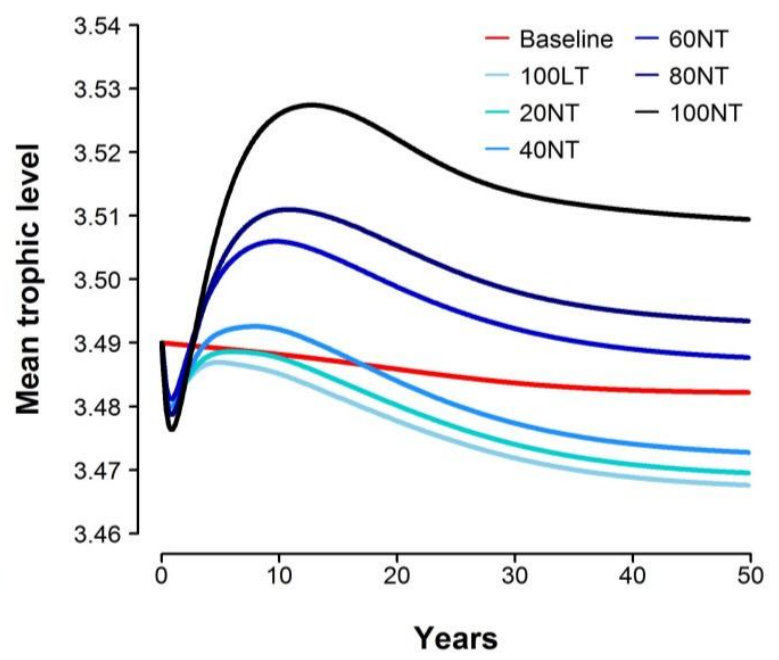


Table 1 Mean percentage change in density of biomass $\left(\mathrm{t} / \mathrm{km}^{2}\right)$ inside and outside of MPAs for 13 functional groups of importance to commercial fisheries at the end of the 50 year simulations relative to when the MPA was introduced, for each MPA management scenario (dark grey shading indicates an increase in biomass).

\begin{tabular}{|c|c|c|c|c|c|c|c|c|c|c|c|c|c|c|c|c|}
\hline \multirow[b]{2}{*}{$\begin{array}{l}\text { Functional } \\
\text { group }\end{array}$} & \multicolumn{2}{|c|}{$100 \mathrm{NT}^{\mathrm{a}}$} & \multicolumn{3}{|c|}{80 NT } & \multicolumn{3}{|c|}{$60 \mathrm{NT}$} & \multicolumn{3}{|c|}{40 NT } & \multicolumn{3}{|c|}{$20 \mathrm{NT}$} & \multicolumn{2}{|c|}{$100 \mathrm{LT}$} \\
\hline & 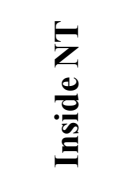 & $\stackrel{\frac{0}{0}}{\stackrel{0}{E}}$ & 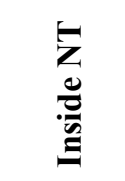 & 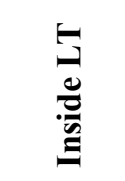 & 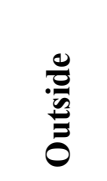 & 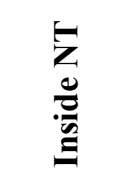 & 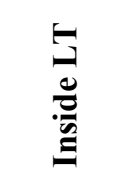 & $\frac{\frac{0}{3}}{0}$ & 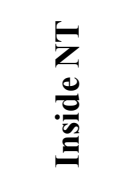 & 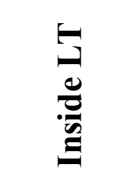 & $\begin{array}{l}\stackrel{0}{0} \\
\stackrel{0}{0} \\
0\end{array}$ & $\begin{array}{l}\bar{z} \\
\stackrel{0}{0} \\
\stackrel{0}{\Xi}\end{array}$ & 卢 & $\underset{\frac{0}{0}}{\stackrel{0}{0}}$ & 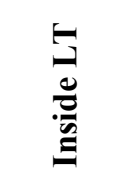 & $\begin{array}{l}\stackrel{0}{0} \\
\stackrel{0}{0} \\
0\end{array}$ \\
\hline Adult cod & 51.38 & -7.83 & 44.27 & 38.52 & -8.12 & 39.32 & 36.22 & -8.27 & 33.89 & 33.70 & -8.40 & 31.71 & 31.67 & -8.51 & 30.14 & -8.54 \\
\hline $\mathrm{Dab}$ & 4.36 & -9.33 & 6.40 & 4.87 & -8.78 & 7.90 & 6.25 & -8.40 & 7.52 & 7.72 & -8.03 & 8.23 & 7.73 & -7.89 & 7.83 & -7.81 \\
\hline Gurnards & 30.67 & -19.21 & 30.86 & 31.69 & -19.43 & 31.85 & 30.09 & -19.51 & 28.26 & 33.37 & -19.52 & 36.26 & 30.78 & -19.49 & 31.93 & -19.59 \\
\hline Hake & 39.84 & 3.59 & 34.87 & 36.05 & 3.35 & 34.99 & 26.86 & 3.44 & 26.57 & 31.48 & 3.37 & 16.97 & 30.96 & 3.47 & 27.87 & 3.64 \\
\hline Mackerel & 58.97 & -3.75 & 60.71 & 57.60 & -3.41 & 64.18 & 55.41 & -3.22 & 53.88 & 65.27 & -2.95 & 52.79 & 62.40 & -2.84 & 60.96 & -2.72 \\
\hline Adult plaice & 2483.06 & 24.75 & 2024.68 & 1581.94 & 16.89 & 1864.40 & 1300.88 & 10.78 & 1486.40 & 1226.47 & 6.04 & 1457.81 & 1100.92 & 2.66 & 1045.54 & 0.23 \\
\hline Pollack & 14.36 & -4.03 & 14.15 & 8.33 & -3.79 & 14.51 & 8.62 & -3.58 & 11.37 & 12.57 & -3.49 & 7.45 & 12.39 & -3.38 & 11.64 & -3.23 \\
\hline Adult seabass & 226.79 & -5.41 & 117.21 & 76.83 & -7.00 & 79.42 & 64.75 & -7.63 & 66.73 & 57.62 & -8.03 & 55.74 & 53.44 & -8.17 & 50.39 & -8.30 \\
\hline Seabream & 9.12 & -2.36 & 9.02 & 8.07 & -2.44 & 8.78 & 8.38 & -2.38 & 7.96 & 8.58 & -2.33 & 8.73 & 8.25 & -2.27 & 8.28 & -2.19 \\
\hline Scad & 8.45 & 0.34 & 7.25 & 5.97 & 0.18 & 6.72 & 4.48 & 0.36 & 4.62 & 3.05 & 0.26 & 2.88 & 2.04 & 0.19 & 1.24 & 0.30 \\
\hline Adult sole & 171.16 & 1.06 & 144.30 & 127.27 & -1.65 & 136.52 & 110.16 & -2.62 & 112.25 & 116.05 & -3.80 & 101.02 & 108.83 & -4.25 & 103.51 & -4.42 \\
\hline Rays and dogfish & 35.33 & 0.07 & 28.38 & 28.17 & -0.62 & 25.31 & 21.89 & -0.96 & 19.75 & 20.76 & -1.31 & 21.50 & 18.38 & -1.30 & 18.03 & -1.27 \\
\hline Adult whiting & 109.10 & -11.74 & 93.54 & 79.95 & -13.65 & 88.10 & 71.90 & -14.22 & 71.43 & 80.76 & -14.31 & 72.41 & 77.79 & -14.01 & 77.00 & -13.76 \\
\hline
\end{tabular}




\section{Supporting Information}

Additional Supporting Information may be found in the online version of this article:

Section S1. Marine protected area network design.

Section S2. Ecosystem model of the eastern English Channel.

Section S3. Marxan marine protected area network portfolios.

Table S1. Details of the conservation features and targets used in the Marxan analysis.

Table S2. Ecopath input data and composition of the species included in each of the 51 functional groups.

Table S3. Economic data for the eastern English Channel fleets.

Table S4. Distribution of the functional groups as assigned to habitat types in the eastern English Channel.

Table S5. Relative dispersal rates, feeding and predation risk parameters of functional groups in Ecospace.

Table S6. Defining fisheries in Ecospace as assigned to habitat types and MPAs in the eastern English Channel.

Table S7. Change in density of biomass inside and outside of MPAs for each functional group at the end of the 50 year simulations.

Figure S1. Eastern English Channel planning region.

Figure S2. Change in catch per fisheries fleet for each MPA management scenario:

Figure S3. Details of total area and cost for the MPA network portfolios identified by Marxan and Marxan with Zones. 


\section{Supporting Information}

Metcalfe, K., Vaz, S., Engelhard, G.H., Villaneuva, MC., Smith, R.J., and Mackinson, S. Evaluating conservation and fisheries management strategies by linking spatial prioritisation software and ecosystem and fisheries modelling tools

\section{Appendix S1. Marine protected area network design methodology}

\section{Conservation feature data}

To represent broad-scale patterns of biodiversity in the eastern English Channel we used a marine habitat map that was modelled using physical and environmental data (Coggan \& Diesing 2011). This map identified seventeen habitats (Table S1) and is based on the European Nature Information System (EUNIS) level 3 and 4 habitat classification hierarchy developed by the European Environment Agency (EEA 2006). The EUNIS level 3 habitats are broken down into three habitat types and coded as follows: infralittoral rock (A3.x); circalittoral rock (A4.x); and sublittoral coarse sediment (A5.x) which was divided into its finer-scale EUNIS level 4 habitats (A5.xx). In addition, we also compiled fine-scale distribution data on 7 priority habitats and 34 species (comprised of 2 algae, 8 invertebrates, 14 seabirds and 10 fish) that are listed by the Convention for the Protection of the Marine Environment of the North East Atlantic (OSPAR 2008) the European Union Birds and Habitats Directives (EC 1979; EC 1992), and/or in national legislation and governmental initiatives (e.g. Marine Conservation Zone Ecological Network Guidance; Table S1). For eight of the fish species we used species distributions modelled using regression quantiles which uses abundance data to identify potential habitat areas where environmental conditions are suitable (Vaz et al. 2008; Carpentier, Martin \& Vaz 2009).

\section{Conservation feature targets}

Given each countries obligation to fulfilling commitments as a signatory to the Convention on Biological Diversity (CBD) and OSPAR (Metcalfe et al. 2013b), and to ensure balanced representation in the planning region, we set targets for each feature in both UK and French waters (Table S1). Targets for the broad-scale EUNIS level 3 habitats were based on the species-area relationship approach and designed to reflect the minimum proportion of habitat area required to represent $80 \%$ of species known to occur in each habitat type (JNCC \& Natural England 2010; Metcalfe et al. 2013a). However, as no targets have been developed for EUNIS level 4 habitat types we based them on the minimum proportion of habitat area required to represent $80 \%$ of species for their parent EUNIS level 3 habitat types (Table S1).

Setting targets for species was more problematic because the distribution maps for many of these species were affected by sampling bias. Thus, we converted the point record data into presence maps by including only one record per planning unit where they occur, and set targets so that there should be a minimum of three replicates spread throughout the planning region (JNCC \& Natural England 2010), with the exception of those features with $<3$ records whose targets were based on the total number of records (Table S1). To represent habitat areas that are potentially suitable for each fish species we used the ,Zonal Statistics" function in ArcGIS (ESRI. 2011) to calculate the mean habitat suitability value for each planning unit. However, as no representation targets have been developed for these species, we set a target of $10 \%$ of the total sum of the habitat suitability values across all planning units for each species. This value was determined from several studies in the scientific literature that have applied targets to conservation features based on recommendations in policy (e.g. Klein et al. 2008; Ban, Picard \& Vincent 2009; Delavenne et al. 2012).

\section{Defining the planning region and planning units}


We divided the eastern English Channel (Figure S1) up into a number of $31.4 \mathrm{~km}^{2}$ planning units ( $\mathrm{n}=$ 1,$180 ; 37,052 \mathrm{~km}^{2}$ ) based on a system developed for an existing Ecospace model of the eastern English Channel (Daskalov, Mackinson \& Mulligan 2011) using the ET GeoWizards Extension in ArcGIS (Tchoukanski 2012). To minimise conflict with other marine resource users we excluded planning units that contained existing and proposed marine aggregate dredging areas and offshore wind farms $\left(\mathrm{n}=281 ; 8,823 \mathrm{~km}^{2}\right.$; Figure S1), and then calculated the amount of each conservation feature in each planning unit using the Conservation Land-Use Zoning (CLUZ) ArcGIS Extension (Smith 2004).

\section{Developing planning unit cost data}

Given that minimising socio-economic impacts is a core objective in MPA design (Ban \& Klein 2009) we collected data on the spatial distribution of fishing effort for eight fishing fleets classified according to different gear types: beam trawls; demersal otter trawls; dredges; pelagic trawls; hooks and lines; nets; seines; and traps and pots. These data were derived from an analysis of vessel monitoring system (VMS) data for vessels $>15 \mathrm{~m}$ in length recorded in the eastern English Channel in $2007-2008$, and included the level of fishing effort reported as the time spent fishing (in hours) per unit area $\left(0.05^{\circ}\right)$ for each fleet. To reflect the relative value of areas for each fleet we used the ,Zonal Statistics"e function in ArcGIS (ESRI. 2011) to calculate the cost for each planning unit based on the mean number of hours fished. Thus, areas with high levels of fishing effort would be more costly to select in Marxan and Marxan with Zones compared to those with low levels of fishing effort, unless they are required to meet targets. Data on smaller inshore vessels were not included in our analysis because high quality spatially explicit VMS data for vessels $<15 \mathrm{~m}$ in the eastern English Channel are currently unavailable.

\section{Running Marxan and Marxan with Zones}

To identify the five different no-take MPA networks we ran Marxan 500 times using simulated annealing followed by iterative improvement, where each run consisted of two million iterations. We used a boundary length modifier (BLM) value of 0.3 as this represented an acceptable trade-off between minimising portfolio fragmentation and cost (Stewart \& Possingham 2005), and identified the five no-take MPA portfolios (hereafter referred to as priority area maps) using an approach developed by Linke et al., (2011). This involved identifying five "clusters" of solutions, based on solution similarity, and then selecting the portfolio with the lowest cost found in each cluster (Linke et al. 2011).

We then used Marxan with Zones to produce five further scenarios for each of the five priority area maps by increasingly allocating $20 \%$ (up to $100 \%$ ) of the targeted amount of each conservation feature to the limited-take zone, with the remaining proportion targeted for protection allocated to the no-take zone. However, we did not specify zone targets for fourteen features which had a restricted distribution in the Marxan portfolios (Table S1), and allowed Marxan with Zones to allocate them to either the no-take or limited-take zone according to the efficient allocation of resources by the optimising algorithm. We ran Marxan with Zones 500 times using simulated annealing followed by iterative improvement technique, where each run consisted of two million iterations, and used the ,planning unit lockee and ,planning unit zone ${ }^{\text {ee }}$ feature to ensure that only planning units selected in each Marxan portfolio would be allocated to the two different management zones. To control for the level of fragmentation within each portfolio we followed the approach devised by Watts et al. (2008) and used a BLM value of 1 and a zone boundary cost that ensured moderate spatial clumping between zones. In addition, Marxan with Zones allows the user to control for the different management objectives associated with each zone and how they contribute to meeting the overall target for each feature. Therefore, we specified the contribution rate of the features allocated to the no-take and limited-take zone to be the same, so that they would contribute equally towards meeting targets. 


\section{Appendix S2. Ecosystem model}

\section{Ecopath model of the eastern English Channel}

Ecopath represents a static mass-balanced snapshot of a trophic network describing the average flows of mass and energy between functional groups during a specified period of time. The Ecopath model of the eastern English Channel was constructed for the period 1995 - 1996, and contained data on 51 functional groups (Villanueva, Ernande \& Mackinson 2009). Each group is represented by a particular species or group of species with similar characteristics (e.g. demography, dietary preference, spatial distribution, age and size) ranging from primary producers to top predators and included two marine mammal, one seabird, twenty-nine fish, fifteen invertebrate, and two primary producers (Table S2). A number of single-species functional groups were defined for species of significance to commercial fisheries (e.g. Hake, John Dory, Mackerel, and Seabream), and the functional groups for a number of fish were subdivided into juveniles and adults (e.g. Cod, Plaice, Seabass, Sole, and Whiting) because of their different habitat requirements, life history and dispersal characteristics. Two non-living groups were also included to represent discard and detritus (Villanueva, Ernande \& Mackinson 2009). The key biological parameters (biomass, rates of production and consumption and diet consumption; Table S2) for each functional group were estimated from stock assessments, fisheries survey data and stomach content analyses (see Villanueva, Ernande \& Mackinson 2009; Daskalov, Mackinson \& Mulligan 2011 and references therein). Mass-balance was achieved by adjusting biomass, diet matrix and consumption and mortality parameters, as described in Villanueva et al. (2009) and Daskalov et al. (2011).

In addition, this model included data on eight fisheries fleets (classified according to different gear types: beam trawl; demersal otter trawl; dredges; pelagic trawl; hooks and lines; nets; traps and pots; and other), which were characterised by their annual extraction of biomass from each functional group (Villanueva, Ernande \& Mackinson 2009). The Ecopath model also included data on the value and total catch of each functional group and the relative profitability of each fleet (Table S2; Table S3). However, to represent current fishing behaviour, and ensure that the Ecospace model reflected fishing effort data used in the Marxan analyses we added an additional fleet (seine) and updated the landings data to reflect the $2007-2008$ distribution of catches among the fleets. These data were obtained from the International Council for the Exploration of the Sea (ICES) landing statistics for ICES area VIId, and were based on the average landings for each functional group.

\section{Ecosim model of the eastern English Channel}

The spatial representation, developed in Ecospace, uses parameters from the calibrated time dynamic model (Ecosim) that determine the strength of interactions among predators and their prey. These interaction strengths are estimated during calibration of the time dynamic model, whereby the models predictions of past trends in the biomass of numerous species in the food web are compared with observed changes recorded in time-series data. Driven by historical data on fishing intensity and primary production, the goal of the time dynamic calibration is to ensure that species persist over time and that the observed historical trends are reflected as best as possible (Daskalov, Mackinson \& Mulligan 2011). Calibration of the ecosystem model thus involved estimating vulnerability parameters using the nonlinear fitting procedure in Ecosim during which the Ecopath model was fitted to time series data on biomass, fishing mortality, and catch derived from stock assessments for 19732006 (see Villanueva, Ernande \& Mackinson 2009; Daskalov, Mackinson \& Mulligan 2011 and references therein).

\section{Appendix S3. Marine protected area network portfolios}

\section{Marxan and Marxan with Zones MPA network portfolios}

The spatial distribution of the different conservation features, patterns of fishing effort and the presence of wind farms and aggregate dredging in the eastern English Channel meant that the five no- 
take MPA portfolios identified by Marxan shared similar spatial patterns and characteristics (Figure 1). The mean area of the MPA networks allocated to the no-take zone in Marxan was $12,460 \mathrm{~km}^{2}$, in contrast the mean area of the MPA networks allocated to the limited-take zone ranged between 2,606 $\mathrm{km}^{2}$ and $12,460 \mathrm{~km}^{2}$ when $20 \%$ to $100 \%$ of the features targeted for protection were allocated to the limited-take zone (Figure S3). In addition, the mean cost of the MPA networks which is the sum of the combined planning unit costs and the boundary costs, decreased from 634,532 for a $100 \%$ no-take MPA network that excluded all fisheries to 529,049 for a 100\% limited-take network that excluded all active gears (Figure S3).

\section{References}

Ban, N.C. \& Klein, C.J. (2009) Spatial socioeconomic data as a cost in systematic marine conservation planning. Conservation Letters, 2, 206-215.

Ban, N.C., Picard, C.R. \& Vincent, A.C.J. (2009) Comparing and Integrating Community-Based and Science-Based Approaches to Prioritizing Marine Areas for Protection. Conservation Biology, 23, 899-910.

Carpentier, A., Martin, C.S. \& Vaz, S. (2009) Channel habitat atlas for marine resource management, final report (CHARM phase II). Interreg 3a Programme. IFREMER, Boulogne-sur-mer, France.

Coggan, R.A. \& Diesing, M. (2011) The seabed habitats of the central English Channel: A generation on from Holme and Cabioch, how do their interpretations match-up to modern mapping techniques? Continental Shelf Research, 31, S132-S150.

Daskalov, G.M., Mackinson, S. \& Mulligan, B. (2011) Modelling possible food-web effects of aggregate dredging in the eastern English Channel. Marine Environmental Protection Fund (MEPF). Ref No: MEPF 08/P37.

Delavenne, J., Metcalfe, K., Smith, R.J., Vaz, S., Martin, C.S., Dupuis, L., Coppin, F. \& Carpentier, A. (2012) Systematic conservation planning in the eastern English Channel: comparing the Marxan and Zonation decision-support tools. Ices Journal of Marine Science, 69, 75-83.

EC (1979) Council Directive 79/409/EEC on the conservation of wild birds. Official Journal L, 103:1.

EC (1992) Council Directive 92/43/EEC on the conservation of natural habitats and of wild fauna and flora. Official Journal L, 206: 0007-0050.

EEA (2006) EUNIS Habitat Classification. European Environment Agency, Copenhagen. Available from http://eunis.eea.europa.eu/habitats.jsp.

ESRI. (2011) ArcGIS Desktop 10. Environmental Systems Research Institute, Redlands, CA, USA.

JNCC \& Natural England (2010) Marine Conservation Zone Project. Ecological Network Guidance. Joint Nature Conservation Committee and Natural England. Available from http://www.jncc.gov.uk/pdf/100608_ENG_v10.pdf.

Klein, C.J., Steinback, C., Scholz, A.J. \& Possingham, H.P. (2008) Effectiveness of marine reserve networks in representing biodiversity and minimizing impact to fishermen: a comparison of two approaches used in California. Conservation Letters, 1, 44-51.

Linke, S., Watts, M., Stewart, R. \& Possingham, H.P. (2011) Using multivariate analysis to deliver conservation planning products that align with practitioner needs. Ecography, 34, 203-207.

Metcalfe, K., Delavenne, J., Garcia, C., Foveau, A., Dauvin, J.-C., Coggan, R., Vaz, S., Harrop, S.R. \& Smith, R.J. (2013a) Impacts of data quality on the setting of conservation planning targets using the species-area relationship. Diversity and Distributions, 19, 1-13. 
Metcalfe, K., Roberts, T., Smith, R.J. \& Harrop, S.R. (2013b) Marine conservation science and governance in North-West Europe: Conservation planning and international law and policy. Marine Policy, 39, 289-295.

OSPAR (2008) OSPAR List of Threatened and/or Declining Species and Habitats. OSPAR Commission. (Reference Number: 2008-6).

Smith, R.J. (2004) Conservation Land-Use Zoning (CLUZ) Software. Durrell Institute of Conservation and Ecology, Canterbury, UK. Available from http://arcscripts.esri.com/details.asp?dbid=13613. .

Stewart, R.R. \& Possingham, H.P. (2005) Efficiency, costs and trade-offs in marine reserve system design. Environmental Modeling \& Assessment, 10, 203-213.

Tchoukanski, I. (2012) ET GeoWizards version 10.2. Available from: http://www.ian-ko.com/.

Vaz, S., Martin, C.S., Eastwood, P.D., Ernande, B., Carpentier, A., Meaden, G.J. \& Coppin, F. (2008) Modelling species distributions using regression quantiles. Journal of Applied Ecology, 45, 204-217.

Villanueva, M.C., Ernande, B. \& Mackinson, S. (2009) Trophic Network. In Channel habitat atlas for marine resource management, final report (CHARM phase II). Interreg 3a Programme. Carpentier, A., Martin, C.S. and Vaz, S. (eds): IFREMER, Boulogne-sur-mer, France.

Watts, M.E., Klein, C.J., Stewart, R.R., Ball, I.R. \& Possingham, H.P. (2008) Marxan With Zones (V1.0.1): Conservation Zoning using Spatially Explicit Annealing. .

\section{Table and Figures}

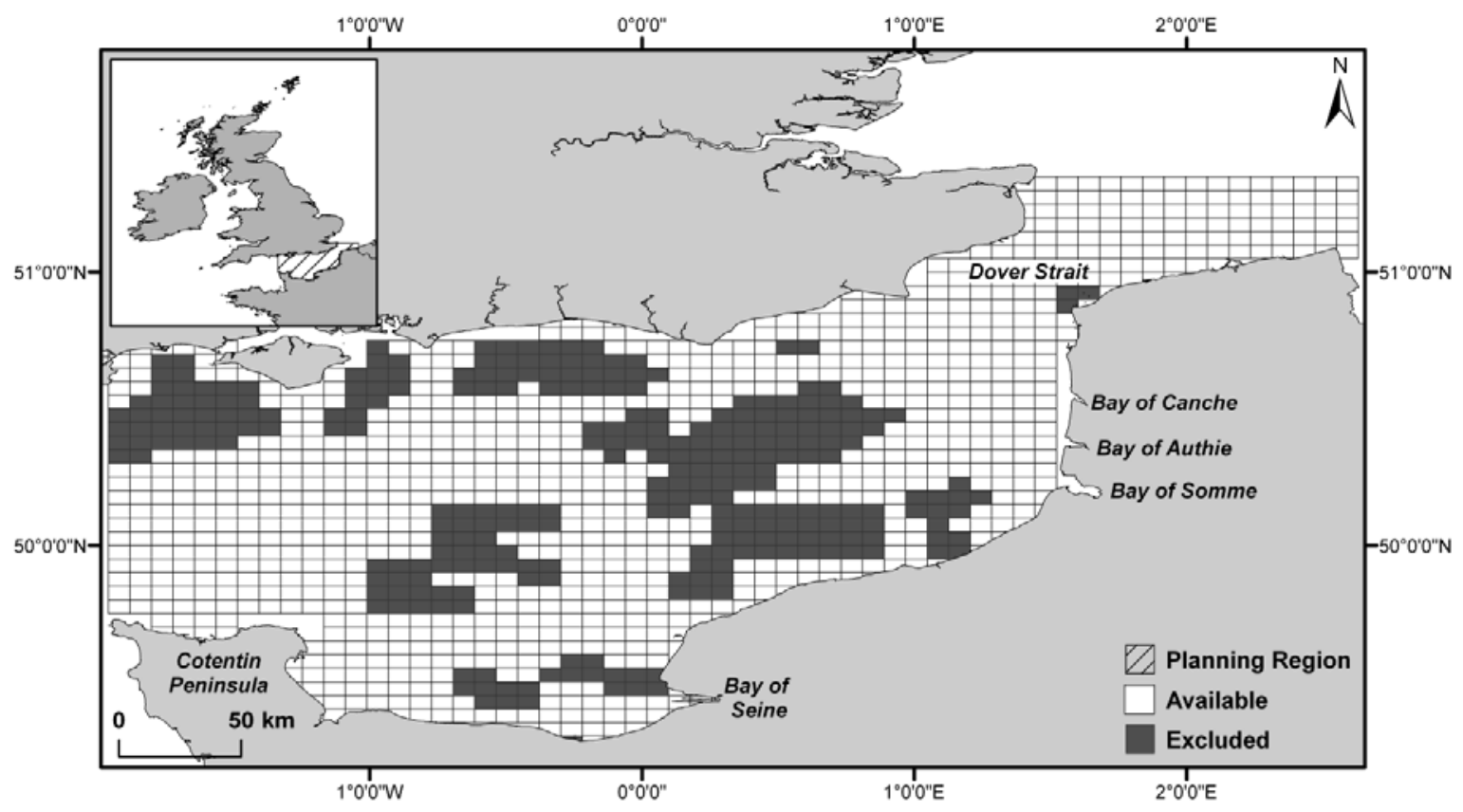

Figure S1 Eastern English Channel, showing the location of the available $(\mathrm{n}=899)$, and excluded planning units $(n=281)$ that contained areas allocated to existing and proposed marine aggregate dredging and offshore wind farms. 

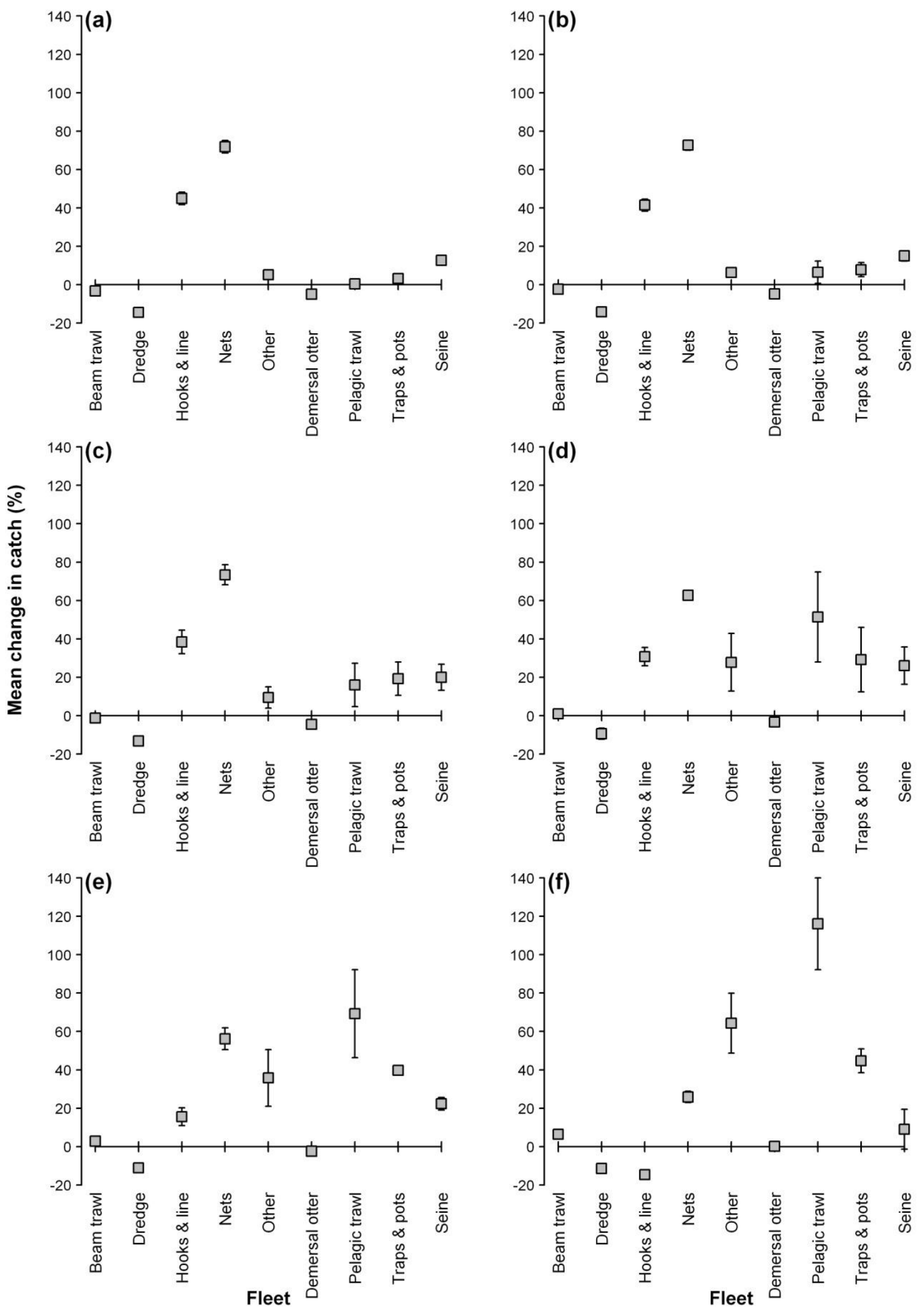

Figure S2 Mean percentage change ( $\pm 95 \%$ confidence intervals) in catch $\left(\mathrm{t} / \mathrm{km}^{2}\right)$ per fisheries fleet for each MPA management scenario: (a) 100\% limited-take; (b) 20\% no-take; (c) 40\% no-take; (d) 60\% no-take; (e) $80 \%$ no-take; and (f) $100 \%$ no-take, relative to baseline scenario with no MPAs. 

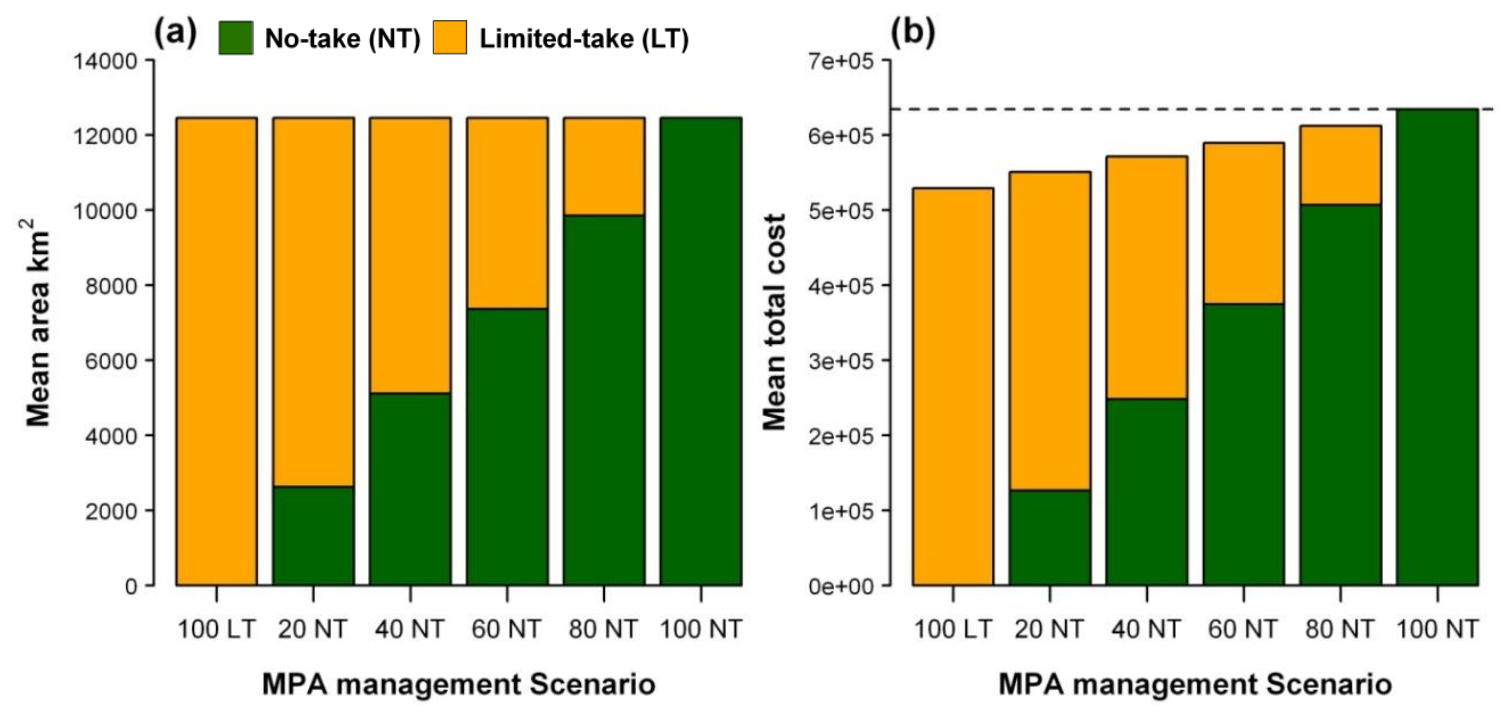

Figure S3 Details of mean: (a) area $\left(\mathrm{km}^{2}\right)$; and (b) cost for the MPA network portfolios identified by Marxan and Marxan with Zones (dashed line indicates mean cost of 100\% no-take MPA networks).

Table S1 Details of the conservation features and targets used in the Marxan analysis (total reflects amount currently in the planning region, and target reflects total amount of each feature targeted for protection).

Total (area $\mathrm{km}^{2}$ /

number of records)
Target (area $\mathbf{k m}^{2}$ /

number of records)

\section{Conservation features}

11.79

77.15

31.61

1144.54

80.36

72.06

1161.68

7186.01

2623.98

1080.58

1066.68

218.50

15.99

8.89
3.60

$25.00^{ \pm}$

$9.99^{ \pm}$

290.71

22.42

$22.70^{ \pm}$

376.38

2328.27

850.17

323.09

318.94

$65.33^{ \pm}$

4.76

$2.65^{ \pm}$ 
UK Infralittoral mixed sediments (A5.43) ${ }^{\mathrm{a} \text { * }}$

UK Circalittoral mixed sediments (A5.44) ${ }^{\mathrm{a}}$ *

FR High energy infralittoral rock (A3.1) ${ }^{\text {a }}$

FR Moderate energy infralittoral rock (A3.2) ${ }^{\mathrm{a}}$

FR Low energy infralittoral rock (A3.3) ${ }^{\mathrm{a}}$

FR High energy circalittoral rock (A4.1) ${ }^{\mathrm{a}}$

FR Moderate energy circalittoral rock (A4.2) ${ }^{\mathrm{a}}$

FR Low energy circalittoral rock (A4.3) ${ }^{\text {a }}$

FR Infralittoral coarse sediment (A5.13) ${ }^{\mathrm{a}}$ *

FR Circalittoral coarse sediment (A5.14) ${ }^{\mathrm{a} *}$

FR Deep circalittoral coarse sediment (A5.15) ${ }^{\mathrm{a}^{*}}$

FR Infralittoral fine sand or muddy sand (A5.23 or A5.24) ${ }^{\mathrm{a}}$ *

FR Circalittoral fine sand or muddy sand (A5.25 or A5.26) ${ }^{\mathrm{a} *}$

FR Deep circalittoral sand (A5.27) ${ }^{\mathrm{a} *}$

FR Infralittoral sandy mud or fine mud (A5.33 or A5.34) ${ }^{\mathrm{a}^{*}}$

FR Circalittoral sandy mud or fine mud (A5.35 or A5.36) ${ }^{\mathrm{a}}$

FR Deep circalittoral mud (A5.37) ${ }^{\mathrm{a} *}$

FR Circalittoral mixed sediments (A5.44) ${ }^{\mathrm{a}}$

UK Intertidal mussel beds (Mytilus edulis) ${ }^{\mathrm{a}, \mathrm{b} \dagger}$

UK Intertidal mudflats $\mathrm{a}, \mathrm{b} \dagger$

UK Littoral chalk communities ${ }^{\mathrm{a}, \mathrm{b} \dagger}$

UK Maerl beds ${ }^{\mathrm{a}, \mathrm{b} \dagger}$

UK Honeycomb worm (Sabellaria alveolata) reefs ${ }^{\text {a, }} \mathrm{b} \dagger$

UK Ross worm (Sabellaria spinulosa) reefs ${ }^{\mathrm{a}, \mathrm{b} \dagger}$

UK Seagrass beds (Zostera marina) ${ }^{\mathrm{a}, \mathrm{b} \dagger}$

FR Intertidal mudflats ${ }^{\mathrm{a}, \mathrm{b} \dagger}$

FR Littoral chalk communities ${ }^{\mathrm{a}, \mathrm{b} \dagger}$

FR Maerl beds ${ }^{a, b \dagger}$

FR Ross worm (Sabellaria spinulosa) reefs ${ }^{\mathrm{a}, \mathrm{b} \dagger}$

FR Seagrass beds (Zostera marina) ${ }^{\mathrm{a}, \mathrm{b} \dagger}$

Species conservation feature data

UK Common maerl (Phymatolithon calcareum) ${ }^{\mathrm{c}, \mathrm{d}, \mathrm{e} \dagger}$

UK Dog whelk (Nucella lapillus) ${ }^{\mathrm{b} \dagger}$

UK Fan mussel (Atrina fragilis) ${ }^{\mathrm{e} \dagger}$

UK Horse mussel (Modiolus modiolus) ${ }^{\mathrm{a}, \mathrm{b} \dagger}$

UK Native/flat oyster (Ostrea edulis) ${ }^{\mathrm{b}, \mathrm{c}, \mathrm{e} \uparrow}$ 
UK Peacocks tail (Padina pavonica) ${ }^{\mathrm{c}, \mathrm{e} \dagger}$

UK Short-snouted seahorse (Hippocampus hippocampus) ${ }^{\mathrm{c}, \mathrm{e}}{ }^{\dagger}$

UK Stalked jellyfish (Haliclystus auricula) ${ }^{\mathrm{c}, \mathrm{e} \dagger}$

UK Stalked jellyfish (Lucernariopsis campanulata) ${ }^{\mathrm{c} \dagger}$

UK Starlet sea anemone (Nematostella vectensis) ${ }^{\mathrm{c}, \mathrm{e} \dagger}$

FR Dog whelk (Nucella lapillus) ${ }^{\mathrm{b}}$

FR Horse mussel (Modiolus modiolus) ${ }^{\mathrm{a}, \mathrm{b} \dagger}$

FR Long-snouted seahorse (Hippocampus guttulatus) ${ }^{\mathrm{c}, \mathrm{e} \dagger}$

FR Native/flat oyster (Ostrea edulis) ${ }^{\mathrm{b}, \mathrm{c}, \mathrm{e} \uparrow}$

FR Ocean quahog (Arctica islandica) ${ }^{\mathrm{b}, \mathrm{c} \dagger}$

FR Short-snouted seahorse (Hippocampus hippocampus) ${ }^{\mathrm{c}, \mathrm{e} \dagger}$

FR Stalked jellyfish (Haliclystus auricula) ${ }^{\mathrm{c}, \mathrm{e} \dagger}$

FR Starlet sea anemone (Nematostella vectensis) ${ }^{\mathrm{c}, \mathrm{e} \uparrow}$

UK Arctic tern (Sterna paradisaea) ${ }^{\mathrm{d} \dagger}$

UK Black-headed gull (Larus ribibundus) ${ }^{\mathrm{d} \dagger}$

UK Black legged kittiwake (Rissa tridactyla) ${ }^{\mathrm{b} \dagger}$

UK Common guillemot (Uria aalge) $)^{\mathrm{b}, \mathrm{d} \dagger}$

UK Common tern (Sterna hirundo $)^{\mathrm{d} \dagger}$

UK European herring gull (Larus argentatus) ${ }^{d \dagger}$

UK European shag (Phalacrocorax aristotelis) ${ }^{\mathrm{d} \dagger}$

UK Great Black-backed gull (Larus marinus) ${ }^{\mathrm{d} \dagger}$

UK Lesser black-backed gull (Larus fuscus) ${ }^{\mathrm{b}, \mathrm{d} \dagger}$

UK Little gull (Larus minutus) ${ }^{\mathrm{d} \dagger}$

UK Mew gull (Larus canus) ${ }^{\mathrm{d} \dagger}$

UK Sandwich tern (Sterna sandvicensis) ${ }^{d \dagger}$

FR Black-headed gull (Larus ribibundus) ${ }^{\mathrm{d} \dagger}$

FR Black legged kittiwake (Rissa tridactyla) ${ }^{\mathrm{b} \dagger}$

1113

FR Common guillemot (Uria aalge) ${ }^{\mathrm{b}, \mathrm{d} \dagger}$

FR Common tern (Sterna hirundo) ${ }^{\mathrm{d} \dagger}$

FR European herring gull (Larus argentatus) ${ }^{\mathrm{d} \dagger}$

FR European shag (Phalacrocorax aristotelis) ${ }^{\mathrm{d} \dagger}$

FR European storm petrel (Hydrobates pelagicus) ${ }^{\mathrm{d} \dagger}$

FR Great Black-backed gull (Larus marinus) ${ }^{\mathrm{d} \uparrow}$

FR Lesser black-backed gull (Larus fuscus) ${ }^{\mathrm{b}, \mathrm{d} \dagger}$ 


\begin{tabular}{|c|c|c|}
\hline FR Mediterranean gull (Larus melanocephalus) ${ }^{\mathrm{d} \dagger}$ & 6 & 3 \\
\hline FR Mew gull (Larus canus) ${ }^{\mathrm{d} \dagger}$ & 23 & 3 \\
\hline FR Sandwich tern (Sterna sandvicensis) ${ }^{d \dagger}$ & 2 & 2 \\
\hline UK Atlantic cod (Gadus morhua) ${ }^{\mathrm{b}, \mathrm{e} \ddagger}$ & 211.41 & 21.14 \\
\hline UK Atlantic mackerel (Scomber scombrus) ${ }^{\mathrm{e}} \ddagger$ & 185.63 & 18.56 \\
\hline UK Common sole (Solea solea) $^{\mathrm{e}} \ddagger$ & 100.42 & 10.04 \\
\hline UK Horse mackerel (Trachurus trachurus) ${ }^{\mathrm{e}} \ddagger$ & 252.11 & 25.21 \\
\hline UK Plaice (Pleuronectes platessa) ${ }^{\mathrm{e}} \ddagger$ & 277.99 & 27.80 \\
\hline UK Spotted ray (Raja montagui) ${ }^{\mathrm{b}}{ }^{*}$ & 139.09 & 13.91 \\
\hline UK Thornback ray (Raja clavata) ${ }^{\mathrm{b} \ddagger}$ & 315.87 & 31.59 \\
\hline UK Whiting (Merlangius merlangus) ${ }^{\mathrm{e}}$ & 148.83 & 14.88 \\
\hline FR Atlantic cod (Gadus morhua) ${ }^{\mathrm{b}, \mathrm{e} \ddagger}$ & 321.96 & 32.20 \\
\hline FR Atlantic mackerel (Scomber scombrus) ${ }^{\mathrm{e}} \ddagger$ & 312.68 & 31.27 \\
\hline FR Common sole (Solea solea) ${ }^{\mathrm{e}} \ddagger$ & 174.82 & 17.48 \\
\hline FR Horse mackerel (Trachurus trachurus) ${ }^{\mathrm{e}} \ddagger$ & 252.11 & 25.21 \\
\hline FR Plaice (Pleuronectes platessa) ${ }^{\mathrm{e} *}$ & 277.99 & 27.80 \\
\hline FR Spotted ray (Raja montagui) ${ }^{\mathrm{b}}$ & 190.56 & 19.06 \\
\hline FR Thornback ray (Raja clavata) ${ }^{\mathrm{b} *}$ & 475.69 & 47.57 \\
\hline FR Whiting (Merlangius merlangus) ${ }^{\mathrm{e}}:$ & 192.02 & 19.20 \\
\hline
\end{tabular}

${ }^{\text {a }}$ Broad-scale habitats and habitat features of conservation interest (FOCI) to be protected within MPAs as identified by the MCZ ecological network guidance (JNCC and Natural England, 2010).

b Threatened and/or declining species and habitats listed by OSPAR (OSPAR, 2008).

${ }^{\mathbf{c}}$ Low or limited mobility species FOCI to be protected within MPAs as identified by the MCZ ecological network guidance (JNCC and Natural England, 2010).

${ }^{d}$ Species listed by EU Birds and Habitats Directives (EC 1979; EC 1992).

${ }^{\mathbf{e}}$ Marine species listed by French and or UK national legislation (e.g. UK BAP).

${ }^{*}$ Refers to habitat targets based on their parent EUNIS level 3 habitats: A5.1x=0.324; A5.2x $=0.299 ;$ A5.3x $=$ 0.298; A5.4x $=0.319$ (JNCC and Natural England, 2010).

${ }^{\dagger}$ Refers to conservation features that are based on point location data.

$\$$ Refers to conservation features that are based on species distribution model data, where the total refers to sum of the mean habitat suitability values across all planning units, and thus has no units.

${ }^{ \pm}$Refers to conservation features which have a restricted distribution in the Marxan solutions and therefore did not have specified zone targets in Marxan with Zones. 


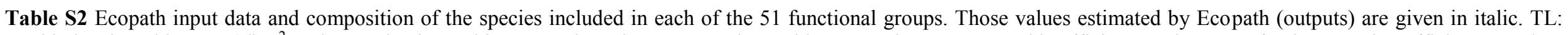

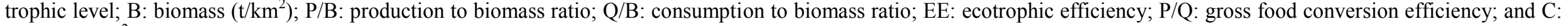

\begin{tabular}{|c|c|c|c|c|c|c|c|c|}
\hline Functional groups & Species & $T L$ & $B\left(t / \mathbf{k m}^{2}\right)$ & P/B (year) & Q/B (year) & $E E$ & $P / Q$ (year) & $C\left(\mathbf{t} / \mathbf{k m}^{2}\right)$ \\
\hline Phytoplankton & & 1.00 & 20.0000 & 40.0000 & - & 0.5150 & - & 0.0000 \\
\hline Phytobenthos & & 1.00 & 64.1200 & 60.0000 & - & 0.5439 & - & 0.0000 \\
\hline Scallops & $\begin{array}{l}\text { King scallop (Pecten maximus), Queen scallop } \\
\text { (Aequipecten opercularis), Variegated scallop } \\
\text { (Chlamys varia) }\end{array}$ & 2.00 & 1.7270 & 0.9000 & 10.0000 & 0.8014 & 0.0900 & 0.4100 \\
\hline Suspension feeders & $\begin{array}{l}\text { White furrow shell (Abra alba), Mussel (Mytilus } \\
\text { edulis), Common cockle (Cerastoderma edule), } \\
\text { Pectinids (Chlamys varia and Aequipecten } \\
\text { opercularis), Banded carpet shell (Paphia } \\
\text { rhomboids) and Clams (Donax sp, Mercenaria } \\
\text { merenaria, Ruditapes philippinarum) }\end{array}$ & 2.00 & 22.4800 & 3.0000 & 20.0000 & 0.1961 & 0.1500 & 0.3980 \\
\hline Deposit feeders & Worms, gastropods and small invertebrates & 2.00 & 20.0000 & 2.5000 & 16.6667 & 0.6625 & 0.1500 & 0.0000 \\
\hline Herbivorous zooplankton & Copepods, cladocerans and tunicates & 2.00 & 27.2219 & 35.0000 & 60.0000 & 0.9000 & 0.5833 & 0.0000 \\
\hline Oysters & European flat oyster (Ostrea edulis) & 2.01 & 2.1000 & 0.9040 & 35.0000 & 0.9945 & 0.0258 & 1.0560 \\
\hline Benthic omnivores & & 2.14 & 134.2664 & 0.9000 & 6.0000 & 0.9000 & 0.1500 & 0.0000 \\
\hline Whelk & Common whelk (Buccinum undatum) & 2.24 & 0.2200 & 1.4000 & 9.3333 & 0.7934 & 0.1500 & 0.0210 \\
\hline Crabs & $\begin{array}{l}\text { Common shore crab (Carcinus maenas), Hermit } \\
\text { crab (Pagurus bernhardus), Velvet swimming crab } \\
\text { (Necora puber) }\end{array}$ & 2.34 & 10.8000 & 1.0500 & 3.0670 & 0.7878 & 0.3424 & 0.0000 \\
\hline Commercial crabs & $\begin{array}{l}\text { Edible crab (Cancer pagurus), Spider crab (Maja } \\
\text { squinado) }\end{array}$ & 2.35 & 4.2720 & 1.0100 & 7.0000 & 0.9000 & 0.1443 & 0.1040 \\
\hline Small demersal fish & $\begin{array}{l}\text { Pogge (Agonus cataphractus), Common dragonet } \\
\text { (Callionymus lyra) }\end{array}$ & 2.52 & 6.7045 & 1.3190 & 10.3840 & 0.8000 & 0.1270 & 0.0040 \\
\hline
\end{tabular}




\begin{tabular}{|c|c|c|c|c|c|c|c|c|}
\hline Shrimps and prawns & Brown shrimp (Crangon crangon) & 2.62 & 12.2554 & 1.7000 & 38.4600 & 0.9000 & 0.0442 & 0.0040 \\
\hline Carnivorous zooplankton & Fish larvae, chaetognaths and ctenophores & 2.71 & 14.7800 & 18.0000 & 23.3300 & 0.9000 & 0.7715 & 0.0000 \\
\hline Other flatfish & & 2.84 & 0.2000 & 1.9900 & 5.4640 & 0.9257 & 0.3642 & 0.0500 \\
\hline Mullet & Grey thick-lipped mullet (Chelon labrosus) & 2.85 & 2.5000 & 0.5000 & 5.1670 & 0.6729 & 0.0968 & 0.0930 \\
\hline Carnivorous megabenthos & $\begin{array}{l}\text { Starfish (Porania (Porania) pulvillus), } \\
\text { Holothurians (Thyone fusus), Featherstar } \\
\text { (Leptometra celtica) and Brittlestars (Ophiothrix } \\
\text { fragilis) }\end{array}$ & 2.90 & 120.0000 & 0.6000 & 6.9350 & 0.5977 & 0.0865 & 0.0000 \\
\hline Lobster & $\begin{array}{l}\text { European Lobster (Homarus gammarus), Spiny } \\
\text { lobster (Palinrus elephas) }\end{array}$ & 2.93 & 0.0130 & 1.0800 & 5.8500 & 0.3633 & 0.1846 & 0.0050 \\
\hline Dab & Limanda limanda & 2.97 & 0.6000 & 0.4000 & 6.4080 & 0.8637 & 0.0624 & 0.0640 \\
\hline Pilchard & Sardina pilchardus & 3.17 & 0.4420 & 0.9880 & 7.2040 & 0.5039 & 0.1372 & 0.0610 \\
\hline Adult sole & Solea solea & 3.17 & 0.3370 & 0.6500 & 5.0630 & 0.9253 & 0.1284 & 0.1960 \\
\hline Small Gadoids & $\begin{array}{l}\text { Pouting (Trisopterus luscus), Poor cod } \\
\text { (Trisopterus minutus) }\end{array}$ & 3.20 & 3.5000 & 1.2430 & 5.1670 & 0.9629 & 0.2406 & 0.0940 \\
\hline Juvenile seabass & Dicentrarchus labrax & 3.24 & 0.0320 & 1.2450 & 6.3480 & 0.1167 & 0.1961 & 0.0000 \\
\hline Adult plaice & Pleuronectes platessa & 3.26 & 0.3500 & 0.6000 & 4.3350 & 0.9881 & 0.1384 & 0.2030 \\
\hline Sandeels & Lesser sand eel (Ammodytes tobianus) & 3.28 & 2.4294 & 1.7400 & 9.1600 & 0.4000 & 0.1900 & 0.0000 \\
\hline Seabream & Spondyliosoma cantharus & 3.30 & 0.1000 & 1.7420 & 11.3530 & 0.1604 & 0.1534 & 0.0200 \\
\hline Gurnards & $\begin{array}{l}\text { Atlantic red gurnard (Aspitriglia cuculus), Tub } \\
\text { gurnard (Chelidonichthys lucernus) and Grey } \\
\text { gurnard (Eutrigla gurnardus) }\end{array}$ & 3.30 & 0.4100 & 0.7300 & 4.7540 & 0.4775 & 0.1536 & 0.0810 \\
\hline Scad & Trachurus trachurus & 3.32 & 0.2300 & 0.6500 & 6.0250 & 0.6002 & 0.0581 & 0.0650 \\
\hline Juvenile plaice & Pleuronectes platessa & 3.32 & 0.1500 & 1.3000 & 8.2180 & 0.3625 & 0.1582 & 0.0000 \\
\hline Cuttlefish & Sepia officinalis & 3.37 & 0.3100 & 3.5000 & 15.0000 & 0.5603 & 0.2333 & 0.0110 \\
\hline
\end{tabular}




\begin{tabular}{|c|c|c|c|c|c|c|c|c|}
\hline Juvenile sole & Solea solea & 3.40 & 0.0600 & 1.3000 & 10.1260 & 0.5480 & 0.1284 & 0.0000 \\
\hline Adult seabass & Dicentrarchus labrax & 3.42 & 0.0680 & 0.5400 & 3.2880 & 0.9811 & 0.1642 & 0.0360 \\
\hline Sprat & Sprattus sprattus & 3.53 & 0.7620 & 1.8520 & 10.1630 & 0.2782 & 0.1822 & 0.0030 \\
\hline Juvenile cod & Gadus morhua & 3.54 & 0.1030 & 2.2680 & 6.0640 & 0.2353 & 0.3740 & 0.0000 \\
\hline Mackerel & Scomber scombrus & 3.55 & 0.9520 & 0.6850 & 6.0470 & 0.8877 & 0.1133 & 0.2150 \\
\hline Rays and dogfish & $\begin{array}{l}\text { Thornback ray (Raja clavata), Painted ray (Raja } \\
\text { microcellata), Cuckoo ray (Leucoraja naevus), } \\
\text { Spotted ray (Raja montagui), Starry ray (Raja } \\
\text { radiate), Undulate ray (Raja undulate), Nurse } \\
\text { hound (Scyliorhinus stellaris), Lesser spotted } \\
\text { dogfish (Scyliorhinus canicula), Portugese dogfish } \\
\text { (Centroscymnus coelolepsis) and Spurdog (Squalus } \\
\text { acanthias) }\end{array}$ & 3.58 & 0.1503 & 0.4400 & 2.5710 & 0.6049 & 0.1711 & 0.0400 \\
\hline Adult cod & Gadus morhua & 3.58 & 0.2200 & 1.2170 & 3.0310 & 0.8444 & 0.4015 & 0.1320 \\
\hline Pollack & Pollachius pollachius & 3.60 & 0.1090 & 0.9200 & 3.3200 & 0.9989 & 0.2848 & 0.0300 \\
\hline Herring & Clupea harengus & 3.62 & 4.7960 & 1.0400 & 4.6000 & 0.4171 & 0.2261 & 0.8570 \\
\hline John Dory & Zeus faber & 3.62 & 0.0300 & 0.8620 & 4.6870 & 0.1194 & 0.1839 & 0.0020 \\
\hline Squid & $\begin{array}{l}\text { Veined squid (Loligo forbesi) and European squid } \\
\text { (Loligo vulgaris) }\end{array}$ & 3.64 & 0.4800 & 3.1500 & 15.0000 & 0.4600 & 0.2100 & 0.2300 \\
\hline Juvenile whiting & Merlangius merlangus & 3.64 & 0.1150 & 2.1360 & 10.9540 & 0.1634 & 0.1950 & 0.0000 \\
\hline Hake & Merluccius merluccius & 3.83 & 0.0970 & 0.6600 & 3.6150 & 0.8886 & 0.1826 & 0.0020 \\
\hline Adult whiting & Merlangius merlangus & 3.88 & 0.7000 & 1.8000 & 4.7090 & 0.9202 & 0.3823 & 0.3660 \\
\hline
\end{tabular}


Greater porkbeard (Phycis blennoides), European

eel (Anguilla anguilla), White anglerfish (Lophius

budegassa), Black scabbarfish (Aphanopus carbo),

Garfish (Belone belone), Atlantic pomfret (Brama

brama), Patagonian toothfish (Dissostichus

eleginoides), Orange roughy (Hoplostehus

atlanticus), Spotted scorpionfish (Scorpaena

plumier) and Anglerfish (Lophius piscatorius)

Seabirds

Toothed cetaceans

Seals

Sharks

Discards

Detritus
Petrels, pelecaniformes, eiders, gulls, terns and

auks

Common dolphin (Delphinus delphis), Harbour porpoise (Phocoena phocoena), Bottlenose dolphin (Tursiops truncates) and Minke whale

(Balaenoptera acutorostrata)

Grey (Halichoerus grypus) and Harbour seal (Phoca vitulina)

Tope (Galeorhinus galeus), Starry smooth-hound (Mustelus asterias) and Smooth-hound (Mustelus mustelus)

\begin{tabular}{|c|c|c|c|c|c|c|}
\hline 3.92 & 0.0018 & 0.4000 & 66.6410 & 0.0000 & 0.0060 & 0.0000 \\
\hline 4.24 & 0.0159 & 0.0980 & 16.8910 & 0.0000 & 0.0058 & 0.0000 \\
\hline 4.38 & 0.0002 & 0.4700 & 15.7520 & 0.0000 & 0.0298 & 0.0000 \\
\hline 4.50 & 0.3070 & 0.1900 & 2.3700 & 0.8915 & 0.0802 & 0.0520 \\
\hline 1.00 & 2.3940 & - & - & 0.5511 & - & 0.0000 \\
\hline 1.00 & 25.0000 & - & - & 0.3936 & - & 0.0000 \\
\hline
\end{tabular}


Table S3 Economic data (relative profitability) for the English Channel fleets based on data reported in Villanueva et al., (2009) and Daskalov et al., (2011).

\begin{tabular}{lccc}
\hline Fleet & Fixed cost (\%) & Sailing cost (\%) & Profit (\%) \\
\hline Beam trawl & 35.30 & 58.70 & 6.00 \\
Demersal otter trawl & 43.10 & 44.00 & 12.90 \\
Dredge & 31.70 & 52.40 & 15.90 \\
Pelagic trawl & 39.90 & 40.00 & 20.10 \\
Hooks and lines & 21.00 & 11.80 & 67.20 \\
Nets & 48.00 & 37.70 & 14.30 \\
Traps and pots & 31.90 & 46.20 & 21.90 \\
Seine $^{\text {a }}$ & 39.90 & 40.00 & 20.10 \\
Other $^{b}$ & 31.90 & 46.20 & 21.90 \\
\hline
\end{tabular}

${ }^{a}$ Cost data for seine fleet based on costs used for pelagic trawl.

${ }^{\mathbf{b}}$ Includes both active and passive fishing gears.

Table S4 Distribution of the functional groups as assigned to habitat types in the eastern English Channel.

\begin{tabular}{|c|c|c|c|c|c|}
\hline Functional groups & All & Offshore $^{a}$ & Intermediate $^{b}$ & $\begin{array}{c}\text { Coastal } \\
\text { homogenous }\end{array}$ & $\begin{array}{c}\text { Coastal } \\
\text { heterogeneous }\end{array}$ \\
\hline Phytoplankton & + & & & & \\
\hline Phytobenthos & + & & & & \\
\hline Scallops & & + & + & + & \\
\hline Suspension feeders & & + & + & + & \\
\hline Deposit feeders & & & + & + & + \\
\hline Herbivorous zooplankton & + & & & & \\
\hline Oysters & & & & + & + \\
\hline Benthic omnivores & & + & + & + & \\
\hline Whelk & & & + & + & \\
\hline Crabs & & + & & & + \\
\hline Commercial crabs & & & + & + & + \\
\hline Small demersal fish & & & + & + & + \\
\hline Shrimps and prawns & & & + & + & + \\
\hline Carnivorous zooplankton & + & & & & \\
\hline Other flatfish & & & + & + & + \\
\hline
\end{tabular}


Mullet

Carnivorous megabenthos

Lobster

Dab

Pilchard

Adult sole

Small Gadoids

Juvenile seabass

Adult plaice

Sandeels

Seabream

Gurnards

Scad

Juvenile plaice

Cuttlefish

Juvenile sole

Adult seabass

Sprat

Juvenile cod

Mackerel

Rays and dogfish

Adult cod

Pollack

Herring

John Dory

Squid

Juvenile whiting

Hake

Adult whiting

Large demersal bottom fish

Seabirds

Toothed cetaceans

Seals

Sharks

Discards

Detritus 
${ }^{a}$ Offshore community - characterised by: hard sediment types, high salinity and warm temperatures, strong tidal currents and greater depths; and associated with: Elasmobranches (sharks, skates and rays), and poor cod.

b Intermediate community - characterised by: coarse sand sediment types; and associated with: Pelagic (sardine, mackerel) and demersal species (dragonets, gurnards, red mullet).

${ }^{c}$ Coastal homogenous community - characterised by: fine sand sediment types, low salinity and temperature, shallow waters and weak currents; and associated with: squids, pelagic (sardine, mackerel, anchovy) and demersal species (black seabream, sandeels, red mullet).

d Coastal heterogeneous community - characterised by: heterogeneous sediment types (from mud to coarse sands); and associated with: pouting, poor cod, and sole preferential of many flatfish species.

Table S5 Relative dispersal rates, feeding and predation risk parameters of functional groups in Ecospace.

\begin{tabular}{|c|c|c|c|c|}
\hline Functional groups & $\begin{array}{l}\text { Original (and } \\
\text { calibrated) dispersal } \\
\text { rate }(\mathrm{km} / \text { year })\end{array}$ & $\begin{array}{c}\text { Dispersal } \\
\text { in bad } \\
\text { habitat }\end{array}$ & $\begin{array}{c}\text { Vulnerability to } \\
\text { predation in bad } \\
\text { habitat }\end{array}$ & $\begin{array}{l}\text { Feeding rate in } \\
\text { bad habitat }\end{array}$ \\
\hline Phytoplankton & $29(29)$ & 2 & 2 & 0.05 \\
\hline Phytobenthos & $29(29)$ & 2 & 2 & 0.05 \\
\hline Scallops & $5(5)$ & 2 & 2 & 0.05 \\
\hline Suspension feeders & $29(29)$ & 2 & 2 & 0.05 \\
\hline Deposit feeders & $29(29)$ & 2 & 2 & 0.05 \\
\hline Herbivorous zooplankton & $29(29)$ & 2 & 2 & 0.05 \\
\hline Oysters & $5(30)$ & 2 & 2 & 0.05 \\
\hline Benthic omnivores & $29(29)$ & 2 & 2 & 0.05 \\
\hline Whelk & $5(30)$ & 2 & 2 & 0.05 \\
\hline Crabs & $5(5)$ & 2 & 2 & 0.05 \\
\hline Commercial crabs & $20(20)$ & 2 & 2 & 0.05 \\
\hline Small demersal fish & $78(78)$ & 2 & 2 & 0.05 \\
\hline Shrimps and prawns & $29(29)$ & 2 & 2 & 0.05 \\
\hline Carnivorous zooplankton & $29(29)$ & 2 & 2 & 0.05 \\
\hline Other flatfish & $75(75)$ & 2 & 2 & 0.05 \\
\hline Mullet & $157(157)$ & 2 & 2 & 0.05 \\
\hline Carnivorous megabenthos & $30(30)$ & 2 & 2 & 0.05 \\
\hline Lobster & $20(12)$ & 2 & 2 & 0.05 \\
\hline $\mathrm{Dab}$ & $75(75)$ & 2 & 2 & 0.05 \\
\hline Pilchard & $157(157)$ & 2 & 2 & 0.05 \\
\hline Adult sole & $78(78)$ & 2 & 2 & 0.05 \\
\hline Small Gadoids & $157(157)$ & 2 & 2 & 0.05 \\
\hline Juvenile seabass & $110(110)$ & 2 & 2 & 0.05 \\
\hline Adult plaice & $75(10)$ & 2 & 2 & 0.05 \\
\hline Sandeels & $50(30)$ & 2 & 2 & 0.05 \\
\hline
\end{tabular}




\begin{tabular}{|c|c|c|c|c|}
\hline Seabream & $157(157)$ & 2 & 2 & 0.05 \\
\hline Gurnards & $157(20)$ & 2 & 2 & 0.05 \\
\hline Scad & $1000(300)$ & 2 & 2 & 0.05 \\
\hline Juvenile plaice & $75(10)$ & 2 & 2 & 0.05 \\
\hline Cuttlefish & $141(141)$ & 2 & 2 & 0.05 \\
\hline Juvenile sole & $75(75)$ & 2 & 2 & 0.05 \\
\hline Adult seabass & $157(150)$ & 2 & 2 & 0.05 \\
\hline Sprat & $78(150)$ & 2 & 2 & 0.05 \\
\hline Juvenile cod & $110(75)$ & 2 & 2 & 0.05 \\
\hline Mackerel & $235(235)$ & 2 & 2 & 0.05 \\
\hline Rays and dogfish & $157(157)$ & 2 & 2 & 0.05 \\
\hline Adult cod & $196(100)$ & 2 & 2 & 0.05 \\
\hline Pollack & $157(157)$ & 2 & 2 & 0.05 \\
\hline Herring & $157(150)$ & 2 & 2 & 0.05 \\
\hline John Dory & $157(157)$ & 2 & 2 & 0.05 \\
\hline Squid & $141(141)$ & 2 & 2 & 0.05 \\
\hline Juvenile whiting & $75(75)$ & 2 & 2 & 0.05 \\
\hline Hake & $196(196)$ & 2 & 2 & 0.05 \\
\hline Adult whiting & $157(157)$ & 2 & 2 & 0.05 \\
\hline Large demersal bottom fish & $157(157)$ & 2 & 2 & 0.05 \\
\hline Seabirds & $275(275)$ & 2 & 2 & 0.05 \\
\hline Toothed cetaceans & $974(974)$ & 2 & 2 & 0.05 \\
\hline Seals & $275(275)$ & 2 & 2 & 0.05 \\
\hline Sharks & $275(275)$ & 2 & 2 & 0.05 \\
\hline Discards & $10(10)$ & 2 & 2 & 0.05 \\
\hline Detritus & $29(29)$ & 2 & 2 & 0.05 \\
\hline
\end{tabular}


Table S6 Defining fisheries in Ecospace as assigned to habitat types and MPAs in the eastern English Channel.

\begin{tabular}{|c|c|c|c|c|c|c|c|}
\hline \multirow[b]{2}{*}{ Functional groups } & \multirow[b]{2}{*}{ All habitats } & \multirow[b]{2}{*}{ Offshore } & \multirow[b]{2}{*}{ Intermediate } & \multirow[b]{2}{*}{ Coastal homogenous } & \multirow[b]{2}{*}{ Coastal heterogeneous } & \multicolumn{2}{|c|}{ MPA management restrictions } \\
\hline & & & & & & No-take MPA & Limited-take MPA \\
\hline Beam trawl & & + & + & & + & & \\
\hline Demersal otter trawl & + & & & & & & \\
\hline Dredge & & & + & & + & & \\
\hline Pelagic trawl & + & & & & & & + \\
\hline Hooks and lines & & & + & & & & + \\
\hline Net & & & & + & + & & + \\
\hline Traps and pots & & + & & & + & & + \\
\hline Seine & + & & & & & & + \\
\hline Other & & & + & + & + & & \\
\hline
\end{tabular}




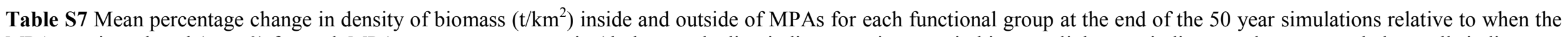

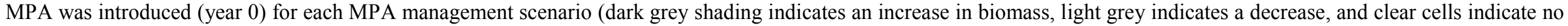
change).

\begin{tabular}{|c|c|c|c|c|c|c|c|c|c|c|c|c|c|c|c|c|}
\hline \multirow[b]{2}{*}{$\begin{array}{l}\text { Functional } \\
\text { group }\end{array}$} & \multicolumn{2}{|c|}{$100 \mathrm{NT}$} & \multicolumn{3}{|c|}{80 NT } & \multicolumn{3}{|c|}{$60 \mathrm{NT}$} & \multicolumn{3}{|c|}{$40 \mathrm{NT}$} & \multicolumn{3}{|c|}{$20 \mathrm{NT}$} & \multicolumn{2}{|c|}{$100 \mathrm{LT}$} \\
\hline & 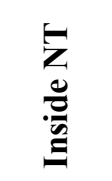 & $\frac{\frac{0}{0}}{\stackrel{0}{E}}$ & 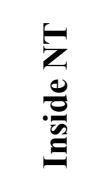 & 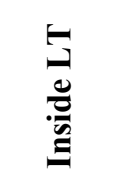 & $\frac{\stackrel{0}{0}}{\stackrel{0}{0}}$ & 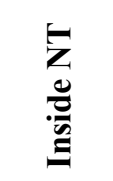 & 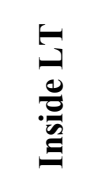 & 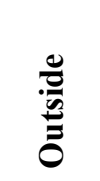 & 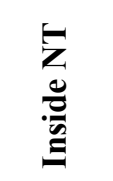 & 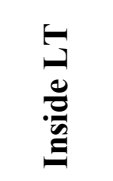 & $\frac{\frac{0}{0}}{\stackrel{0}{0}}$ & 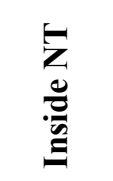 & 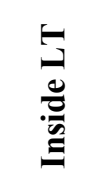 & $\frac{\stackrel{0}{*}}{\stackrel{0}{E}}$ & 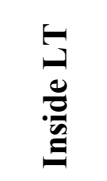 & 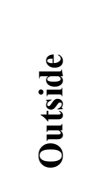 \\
\hline Phytoplankton & -0.10 & 0.70 & -0.07 & -0.14 & 0.71 & -0.07 & -0.18 & 0.71 & -0.13 & -0.18 & 0.70 & -0.24 & -0.18 & 0.69 & -0.20 & 0.68 \\
\hline Phytobenthos & -1.04 & 0.64 & -1.00 & -0.70 & 0.65 & -0.91 & -0.58 & 0.64 & -0.74 & -0.55 & 0.66 & -0.75 & -0.43 & 0.68 & -0.41 & 0.68 \\
\hline Scallops & 21.37 & -9.99 & 20.64 & 6.90 & -8.82 & 17.21 & 8.40 & -6.86 & 17.12 & 11.22 & -6.93 & 18.47 & 10.61 & -6.39 & 11.02 & -5.98 \\
\hline Suspension feeders & -0.93 & 0.99 & -0.88 & -0.71 & 0.97 & -0.77 & -0.57 & 0.99 & -0.63 & -0.50 & 0.99 & -0.75 & -0.37 & 0.99 & -0.37 & 0.99 \\
\hline Deposit feeders & -1.49 & 1.08 & -1.50 & -1.11 & 1.09 & -1.40 & -0.84 & 1.09 & -1.15 & -0.75 & 1.13 & -1.17 & -0.52 & 1.16 & -0.50 & 1.17 \\
\hline $\begin{array}{l}\text { Herbivorous } \\
\text { zooplankton }\end{array}$ & 0.83 & -1.49 & 0.72 & 0.81 & -1.53 & 0.72 & 0.73 & -1.55 & 0.67 & 0.70 & -1.55 & 0.91 & 0.61 & -1.55 & 0.64 & -1.55 \\
\hline Oysters & 474.86 & 1.96 & 387.57 & 87.96 & 2.15 & 261.87 & 38.57 & 3.44 & 114.61 & 26.28 & -1.43 & 65.44 & -12.66 & -4.78 & -21.28 & -5.04 \\
\hline Benthic omnivores & 0.16 & -0.12 & 0.08 & 0.19 & -0.16 & 0.09 & 0.13 & -0.19 & 0.04 & 0.09 & -0.20 & 0.06 & 0.08 & -0.21 & 0.07 & -0.22 \\
\hline Whelk & -6.77 & -2.96 & -6.52 & -7.60 & -2.77 & -5.93 & -6.40 & -2.59 & -6.31 & -6.18 & -2.48 & -6.20 & -5.63 & -2.39 & -5.48 & -2.33 \\
\hline Crabs & -4.57 & -0.64 & -4.88 & -3.61 & -0.70 & -4.71 & -3.66 & -0.69 & -4.25 & -3.77 & -0.67 & -3.89 & -3.47 & -0.61 & -3.29 & -0.60 \\
\hline Commercial crabs & -0.40 & -0.83 & 0.49 & -6.25 & -0.45 & 0.59 & -5.83 & 0.39 & -1.64 & -5.72 & 1.27 & -2.20 & -5.21 & 1.82 & -5.09 & 2.33 \\
\hline Small demersal fish & -17.45 & 0.03 & -15.80 & -15.25 & 0.43 & -15.05 & -13.22 & 0.65 & -12.79 & -12.68 & 0.98 & -12.95 & -11.41 & 1.15 & -10.90 & 1.25 \\
\hline $\begin{array}{l}\text { Shrimps and } \\
\text { prawns }\end{array}$ & -12.12 & -19.70 & -11.67 & -11.81 & -1.84 & -11.37 & -10.45 & -1.71 & -10.34 & -10.56 & -1.62 & -11.74 & -9.58 & -1.53 & -9.63 & -1.48 \\
\hline $\begin{array}{l}\text { Carnivorous } \\
\text { zooplankton }\end{array}$ & -1.27 & 1.42 & -1.01 & 0.20 & 1.48 & -0.78 & 0.47 & 1.46 & -0.21 & 0.69 & 1.55 & 0.27 & 0.95 & 1.59 & 1.04 & 1.61 \\
\hline Other flatfish & 10.93 & -3.96 & 9.91 & 3.50 & -3.40 & 9.39 & 4.32 & -3.08 & 6.91 & 5.07 & -2.70 & 4.47 & 5.29 & -2.46 & 4.79 & -2.25 \\
\hline Mullet & -0.41 & 4.41 & 0.03 & 0.15 & 4.28 & 0.09 & 0.66 & 4.09 & 0.70 & 1.36 & 4.01 & 0.01 & 1.87 & 3.95 & 1.78 & 3.89 \\
\hline $\begin{array}{l}\text { Carnivorous } \\
\text { megabenthos }\end{array}$ & 1.03 & 1.62 & 1.04 & 1.00 & 1.59 & 1.05 & 1.02 & 1.55 & 0.91 & 1.12 & 1.54 & 0.91 & 1.08 & 1.52 & 1.05 & 1.51 \\
\hline Lobster & 1.38 & -38.15 & 6.90 & -36.37 & -38.31 & 10.79 & -40.26 & -38.01 & 1.40 & -41.46 & -35.65 & -4.98 & -42.66 & -35.39 & -45.05 & -35.92 \\
\hline $\mathrm{Dab}$ & 4.36 & -9.33 & 6.40 & 4.87 & -8.78 & 7.90 & 6.25 & -8.40 & 7.52 & 7.72 & -8.03 & 8.23 & 7.73 & -7.89 & 7.83 & -7.81 \\
\hline Pilchard & 18.58 & 3.27 & 16.43 & 12.63 & 4.03 & 13.96 & 10.86 & 4.99 & 11.47 & 8.22 & 5.43 & 10.45 & 7.36 & 5.98 & 6.06 & 6.61 \\
\hline
\end{tabular}




\begin{tabular}{|c|c|c|c|c|c|c|c|c|c|c|c|c|c|c|c|c|}
\hline Adult sole & 171.16 & 1.06 & 144.30 & 127.27 & -1.65 & 136.52 & 110.16 & -2.62 & 112.25 & 116.05 & -3.80 & 101.02 & 108.83 & -4.25 & 103.51 & -4.42 \\
\hline Small Gadoids & -7.67 & 1.11 & -6.84 & -6.65 & 1.42 & -6.48 & -5.83 & 1.57 & -5.39 & -6.04 & 1.72 & -5.86 & -5.45 & 1.78 & -5.39 & 1.82 \\
\hline Juvenile seabass & -15.74 & -3.82 & -10.53 & -6.52 & -2.14 & -8.35 & -4.00 & -1.45 & -5.38 & -3.47 & -0.60 & -4.62 & -1.55 & 0.15 & -1.25 & 0.49 \\
\hline Adult plaice & 2483.06 & 24.75 & 2024.68 & 1581.94 & 16.89 & 1864.40 & 1300.88 & 10.78 & 1486.40 & 1226.47 & 6.04 & 1457.81 & 1100.92 & 2.66 & 1045.54 & 0.23 \\
\hline Sandeels & -30.62 & -40.36 & -29.54 & -29.85 & -39.74 & -27.30 & -27.69 & -39.23 & -25.70 & -23.64 & -38.20 & -18.81 & -25.59 & -37.78 & -23.15 & -37.61 \\
\hline Seabream & 9.12 & -2.36 & 9.02 & 8.07 & -2.44 & 8.78 & 8.38 & -2.38 & 7.96 & 8.58 & -2.33 & 8.73 & 8.25 & -2.27 & 8.28 & -2.19 \\
\hline Gurnards & 30.67 & -19.21 & 30.86 & 31.69 & -19.43 & 31.85 & 30.09 & -19.51 & 28.26 & 33.37 & -19.52 & 36.26 & 30.78 & -19.49 & 31.93 & -19.59 \\
\hline Scad & 8.45 & 0.34 & 7.25 & 5.97 & 0.18 & 6.72 & 4.48 & 0.36 & 4.62 & 3.05 & 0.26 & 2.88 & 2.04 & 0.19 & 1.24 & 0.30 \\
\hline Juvenile plaice & -2.67 & -17.87 & -4.18 & 4.23 & -18.54 & -2.67 & -0.59 & -19.12 & -5.59 & 1.36 & -18.64 & 9.79 & -2.42 & -18.62 & -0.52 & -18.61 \\
\hline Cuttlefish & -6.28 & 4.53 & -6.35 & -5.71 & 4.71 & -6.08 & -6.10 & 4.84 & -5.67 & -6.66 & 4.98 & -5.97 & -6.15 & 5.07 & -6.15 & 5.13 \\
\hline Juvenile sole & -15.71 & -3.13 & -13.47 & -9.26 & -2.27 & -12.83 & -5.63 & -1.97 & -8.29 & -8.01 & -1.21 & -8.08 & -5.20 & -0.60 & -5.27 & -0.31 \\
\hline Adult seabass & 226.79 & -5.41 & 117.21 & 76.83 & -7.00 & 79.42 & 64.75 & -7.63 & 66.73 & 57.62 & -8.03 & 55.74 & 53.44 & -8.17 & 50.39 & -8.30 \\
\hline Sprat & -8.92 & -0.14 & -7.08 & -3.89 & 0.40 & -5.14 & -3.55 & 0.52 & -3.36 & -2.44 & 1.04 & -2.37 & -1.20 & 1.25 & -0.86 & 1.38 \\
\hline Juvenile cod & -3.43 & 8.24 & -5.06 & -4.84 & 8.18 & -4.42 & -6.54 & 8.18 & -5.50 & -6.60 & 8.23 & -6.25 & -6.56 & 8.23 & -6.87 & 8.82 \\
\hline Mackerel & 58.97 & -3.75 & 60.71 & 57.60 & -3.41 & 64.18 & 55.41 & -3.22 & 53.88 & 65.27 & -2.95 & 52.79 & 62.40 & -2.84 & 60.96 & -2.72 \\
\hline Rays and dogfish & 35.33 & 0.07 & 28.38 & 28.17 & -0.62 & 25.31 & 21.89 & -0.96 & 19.75 & 20.76 & -1.31 & 21.50 & 19.45 & -1.30 & 18.03 & -1.27 \\
\hline Adult cod & 51.38 & -7.83 & 44.27 & 38.52 & -8.12 & 39.32 & 36.22 & -8.27 & 33.89 & 33.70 & -8.40 & 31.71 & 31.67 & -8.51 & 30.14 & -8.54 \\
\hline Pollack & 14.36 & -4.03 & 14.15 & 8.33 & -3.79 & 14.51 & 8.62 & -3.58 & 11.37 & 12.57 & -3.49 & 7.45 & 12.39 & -3.38 & 11.64 & -3.23 \\
\hline Herring & 486.21 & 46.23 & 301.12 & 90.63 & 26.12 & 202.18 & 75.21 & 22.73 & 83.46 & 38.43 & 6.83 & 48.13 & 18.00 & 3.92 & 7.56 & 2.44 \\
\hline John Dory & -1.52 & 3.02 & -1.03 & -1.03 & 3.36 & -1.00 & -0.56 & 3.53 & -0.13 & -0.48 & 3.69 & 0.29 & -0.09 & 3.69 & 0.13 & 3.69 \\
\hline Squid & -6.72 & -10.75 & -5.67 & -6.18 & -10.61 & -5.30 & -4.40 & -10.37 & -4.24 & -4.52 & -10.13 & -3.82 & -4.12 & -9.97 & -3.94 & -9.93 \\
\hline Juvenile whiting & 16.22 & -3.57 & 1.25 & -10.48 & -3.98 & -6.86 & -9.25 & -3.62 & -10.75 & -8.99 & -3.72 & -13.23 & -9.95 & -3.46 & -9.72 & -3.27 \\
\hline Hake & 39.84 & 3.59 & 34.87 & 36.05 & 3.35 & 34.99 & 26.86 & 3.44 & 26.57 & 31.48 & 3.37 & 16.97 & 30.96 & 3.47 & 27.87 & 3.64 \\
\hline Adult whiting & 109.10 & -11.74 & 93.54 & 79.95 & -13.65 & 88.10 & 71.90 & -14.22 & 71.43 & 80.76 & -14.31 & 72.41 & 77.79 & -14.01 & 77.00 & -13.76 \\
\hline $\begin{array}{l}\text { Large demersal } \\
\text { bottom fish }\end{array}$ & 17.32 & -3.54 & 15.94 & 15.30 & -3.50 & 15.32 & 14.19 & -3.36 & 12.90 & 15.99 & -3.16 & 15.58 & 14.75 & -3.09 & 15.04 & -2.99 \\
\hline Seabirds & 3.30 & -9.71 & -1.21 & 1.29 & -11.31 & -0.78 & -1.69 & -11.50 & -4.09 & -3.35 & -12.52 & -1.87 & -4.97 & -12.65 & -5.18 & -13.03 \\
\hline Toothed cetaceans & -5.52 & -4.43 & -4.47 & -4.59 & -4.12 & -3.88 & -3.88 & -3.92 & -3.46 & -3.50 & -3.87 & -3.12 & -3.30 & -3.71 & -3.23 & -3.71 \\
\hline Seals & 51.05 & 0.00 & 31.32 & 23.82 & 0.00 & 25.00 & 20.12 & 0.00 & 19.97 & 21.09 & 0.00 & 16.02 & 19.59 & 0.00 & 15.65 & 0.00 \\
\hline
\end{tabular}




\begin{tabular}{|c|c|c|c|c|c|c|c|c|c|c|c|c|c|c|c|c|}
\hline Sharks & 4.68 & -18.94 & 2.31 & 7.76 & -19.06 & 3.74 & 0.88 & -19.00 & -1.65 & 2.53 & -18.69 & 7.38 & -1.14 & -18.82 & -0.79 & -18.71 \\
\hline Discards & -45.75 & 28.27 & -47.69 & -26.638 & 23.11 & -46.23 & -37.75 & 20.50 & -48.26 & -40.11 & 17.61 & -47.40 & -42.26 & 16.49 & -43.58 & 15.76 \\
\hline Detritus & -0.44 & 0.47 & -0.46 & -0.18 & 0.46 & -0.39 & -0.09 & 0.45 & -0.27 & -0.04 & 0.47 & -0.21 & 0.05 & 0.49 & 0.07 & 0.48 \\
\hline
\end{tabular}

